\title{
1622 o la canonización de la Reforma Católica*
}

\section{2 or the Canonization of the Catholic Reformation}

\author{
Fermín LABARGA ${ }^{* *}$ \\ Universidad de Navarra \\ Scopus Author ID 55232207500 \\ http://orcid.org/0000-0002-8088-4269 \\ flabarga@unav.es
}

\begin{abstract}
The canonization of 1622 , in wich Blessed Isidore the Farmer, Ignatius Loyola, Francis Xavier, Teresa of Avila and Philip Neri were inscribed in the Canon of Saints, was memorable for several reasons. It's period of gestation was not easy. Pope Paul $v$ had decided to canonize Isidore the Farmer, a decisión that was accepted by his successor, Gregory XV. The strong pressure to which the Pope was subjected both by the Catholic Monarchs and by the Orders to which the new saints belonged, especially the Jesuits, determined their joint canonization in the short term, first adding Blessed Teresa, then Ignatius and Xavier, and, finally, in order to avoid an exclusively Spanish ceremony, at the request of the Congregation itself, Philip Neri. Without denying the political side of the canonization, this paper offers several convergent lines of interpretation in order to demonstrate that the canonization in 1622 was not only the canonization of the protagonists of the Catholic Reformation but, symbolically, of the Church's own Reformation itself.
\end{abstract}

Keywords: Canonization, Isidore the Farmer, Ignatius Loyola, Francis Xavier, Teresa of Avila, Philip Neri, Catholic Reformation.
Resumen: La canonización de 1622, en que se inscribió en el catálogo de los santos a los beatos Isidro Labrador, Ignacio de Loyola, Francisco Javier, Teresa de Jesús y Felipe Neri, fue memorable por diversas razones. Su gestación no fue sencilla. Paulo v había decidido canonizar al beato Isidro labrador, lo que asumió también su sucesor, Gregorio XV. Las fuertes presiones a las que fue sometido tanto por los monarcas católicos como por las órdenes a las que pertenecían los nuevos santos, especialmente los jesuitas, determinaron a corto plazo su canonización conjunta, agregándose primero la beata Teresa, luego Ignacio de Loyola y Francisco Javier $y$, finalmente, con el fin de evitar una ceremonia exclusivamente española, a instancias de la propia Congregación, el beato Felipe Neri. Sin negar el componente político de la canonización, en el presente artículo se ofrecen otras líneas de interpretación convergentes con el fin de demostrar que la de 1622 fue no sólo la canonización de los protagonistas de la Reforma Católica sino, simbólicamente, de la propia Reforma de la Iglesia en si misma.

Palabras clave: Canonización, Isidro Labrador, Ignacio de Loyola, Francisco Javier, Teresa de Jesús, Felipe Neri, Reforma Católica.

* Este trabajo ha sido realizado con la ayuda del Centro Español de Estudios Eclesiásticos anejo a la Iglesia Nacional Española de Santiago y Montserrat en Roma en el marco de los proyectos de investigación del curso 2018-2019.

** Este artículo se encuadra dentro del Plan de Investigación de la Universidad de Navarra (PIUNA) 2018-2020: «Trento en el Mundo hispánico: Renovación individual, social y cultural». 
Algo nunca antes visto tuvo lugar en Roma el 12 de marzo de 1622. En dicho día «fuit facta celebris ab omni saeculo memoranda canonizatio» ${ }^{1}$, en la que el papa Gregorio XV mandaba inscribir en el catálogo de los santos a cinco nuevos «héroes» de la Cristiandad: san Isidro labrador, san Ignacio de Loyola, san Francisco Javier, santa Teresa de Jesús y san Felipe Neri. Los romanos, irónicos y todavía conmocionados por il sacco de Roma, dijeron con sorna que «oggi il Papa ha canonizzato quattro spagnoli e un santo»...

Dejando aparte la anécdota, cabe tener en cuenta que dicha canonización, en efecto, ha pasado a la historia por varios motivos. Como ya señalaba Próspero Lambertini en su monumental obra De beatificatione Servorum Dei et canonizatione beatorum, esta fue la primera vez en que se realizó una canonización colectiva, en una misma y única ceremonia ${ }^{2}$. Por otra parte, aunque ya se percibía, con el paso de los siglos, la magnitud de los santos canonizados en aquella memorable ocasión ha aumentado sin cesar, y resulta difícil encontrar otra canonización que se le asemeje en este sentido, si bien no faltaron intentos posteriores de emularla e, incluso, superarla ${ }^{3}$.

En tercer lugar, la aún reciente Congregación de Ritos, erigida en 1585, seguía perfilando y perfeccionando los procedimientos, singularmente el referido al estadio intermedio de la beatificación, por la que tuvieron que pasar los cinco nuevos santos canonizados. También por vez primera.

Y no puede obviarse tampoco la procedencia de los nuevos santos, cuatro de ellos oriundos de España, como pronto advirtieron no solo el pueblo romano sino también las cancillerías de las principales potencias. Contra lo que cabría pensar, la presencia de santos españoles en el calendario romano era muy exigua. Junto con

1 BNE, Mss/2232, f. 81.

2 Benedictus XIV (Próspero LAMBERTINI), De servorum Dei beatificatione et beatorum canonizatione, Librería Editrice Vaticana, I/1, Città del Vaticano 2010, 713: «Tempore quoque Gregorii XV, cum quaesitum fuisset in sacrorum rituum Congregatione, an plures Beati unica Canonizatione possent canonizari, affirmanter responsum fuit, ut mox videbitur: idemque Pontifex simul canonizavit BB. Philippum Nerium, Ignatium de Loyola, Franciscum Xaverium, Isidorum Agricolam, Teresiam».

3 Clemente X canonizaba conjuntamente el 12 de abril de 1671 a san Cayetano de Thiene, san Francisco de Borja, san Luis Bertrán, san Felipe Benicio y santa Rosa de Lima; Alejandro VIII, el 16 de octubre de 1690 a san Juan de Capistrano, san Juan de Dios, san Juan de Sahagún, san Lorenzo Giustiniani y san Pascual Baylon; Benedicto XIV, el 29 de junio de 1746 a san Camilo de Lelis, santa Catalina de Ricci, san Fidel de Sigmaringa, san José de Leonisa y san Pedro Regalado. Solo Clemente XIII se atrevió a superar el número de cinco nuevos santos, con la canonización de seis: San Jerónimo Emiliani, santa Juana Francisca Fremiot de Chantal, san Juan de Kety, san José de Calasanz, san José de Cupertino y san Serafín de Montegranaro, celebrada el 16 de julio de 1767. En tiempos recientes se ha superado dicho número en numerosas ocasiones, especialmente en las canonizaciones colectivas de mártires. 
algunos santos de la antigüedad cristiana, como los mártires Lorenzo y Vicente, y el papa Dámaso (tradicionalmente considerado hispano), hasta el siglo XVI sólo habían logrado introducirse en el santoral de la Iglesia universal dos miembros de la Orden de Predicadores: su fundador, santo Domingo de Guzmán, cuya causa había sido promovida, obviamente, por sus frailes y desde Italia, máxime cuando su sepulcro se encuentra en Bolonia, y el popular y apocalíptico predicador san Vicente Ferrer, canonizado por su paisano Calixto III en 1455. De este modo, durante los siglos medievales, fueron canonizados un buen número de santos procedentes de Italia, Francia, Inglaterra y Alemania, e incluso del este de Europa y de Escandinavia, pero no de España, quizás por «el escaso empeño en promover las causas» observado en las autoridades tanto eclesiásticas como civiles ${ }^{4}$.

El estallido de la revuelta protestante y las críticas de los reformadores a la veneración de los santos, unidas a otras surgidas en el propio seno de la Iglesia por el escaso rigor con que se habían desarrollado algunos procesos, tuvo dos consecuencias inmediatas: por una parte, los papas interrumpieron la celebración de canonizaciones; por otra, comenzó a desarrollarse un procedimiento cada vez más serio y riguroso para la averiguación de la santidad de vida y la certificación de los milagros obrados por los candidatos a la gloria de los altares. Precisamente, para encargarse de supervisar y certificar este proceso Sixto V erigía en 1588 la Congregación de Ritos $^{5}$.

En sus primeros tiempos, la Congregación fue trabajando ad experimentum, implementando cauces para la averiguación de todos los extremos precisos de la vida, muerte, escritos y milagros de los candidatos. Una de las medidas introducidas de mayor calado, ya que quedó establecida de modo permanente, fue la de la beatificación entendida como proceso previo y necesario antes de la canonización ${ }^{6}$. El término constituye un neologismo que aparece por vez primera en una carta, fechada el 7 de octubre de 1585, que enviaba el rey Felipe II a su embajador en Roma, conde de Olivares, urgiéndole a recabar del Papa el reconocimiento para un culto meramente local tributado al dominico Luis Bertrán en Valencia. La beatificación equivaldría, por tanto, a una especie de indulto apostólico que permitiría un culto local, o en el seno de una orden religiosa, no solo de santos antiguos sino también de

4 Thomas DANDELET, «Celestiali eroi» e lo «splendor d'Iberia». La canonizzazione dei santi spagnoli a Roma in età moderna, en Giovanna FIUME (ed.), Il santo patrono e la città. San Benedetto il Moro: culti, devozioni, strategie di età moderna, Venecia, 2000, p. 185.

5 Giovanni PaPA, Le cause di canonizzazione nel primo periodo della Congregazione dei Riti (1588-1634), Urbaniana University Press, Roma, 2001.

6 Fabijan Veraja, La beatificazione. Storia, problemi, prospettive, Roma, 1983; PAPA, Le cause di canonizzazione, pp. 147-214; Miguel GOTOR, Chiesa e santità nell'Italia moderna, Laterza, Roma-Bari, 2004, pp. 30-78. 
difuntos muertos recientemente con fama de santidad. Poco a poco, el término y el concepto que suponía fueron instalándose en la praxis de la Curia romana. El primer santo que pasó por el estadio previo de la beatificación, a se stante, fue san Juan de Sahagún, en 1601, mientras que el último santo canonizado sin beatificación previa fue san Carlos Borromeo en 16107. De hecho, Clemente VIII estableció en 1602 una efímera Congregación de los Beatos ${ }^{8}$, luego reasumida en la de Ritos, con la finalidad de controlar la explosión de la devoción popular en torno a determinadas personas recientemente fallecidas en olor de santidad, entre los que se encontraban los fundadores de algunas nuevas familias religiosas ${ }^{9}$. En cierta forma, dicha congregación se situaba en un estratégico lugar intermedio entre la Congregación de Ritos y el Santo Oficio, que pretendía controlar de manera eficiente el acceso al reconocimiento de la santidad. En sus primeros compases, la práxis fue aquilatándose mientras se estaban llevando adelante las causas de los santos que fueron canonizados en 1622. Todavía en estos años ejercían un papel muy relevante los auditores de la Rota Romana ya que cada proceso era examinado por tres de ellos, que emitían un juicio favorable o desfavorable tras un exhaustivo examen; entre ellos cabe mencionar a Francisco Peña, decano de la Rota desde 1610 hasta su fallecimiento en 1612, y a Alfonso Manzanedo de Quiñones, auditor por la Corona de Castilla, que participó activamente en los procesos de san Isidro, San Ignacio y santa Teresa (de la que luego escribió una biografía ${ }^{10}$ ), así como en los de beatificación de Tomás de Villanueva, Pascual Baylon e Isabel de Portugal.

7 Angelo TurChINI, La fabbrica di un Santo. Il processo di canonizzazione di Carlo Borromeo e la Controriforma, Marietti, Casale Monferrato, 1984.

8 Miguel GOTOR, I beati del Papa. Santità, Inquisizione e obbedienza in età moderna, Leo S. Olschki, Florencia, 2002.

9 Como san Ignacio de Loyola y san Felipe Neri, muy distintos en cuanto a la repercusión de su fama de santidad, ya que mientras en torno al sepulcro del primero se manifestaba un movimiento devocional concentrado en torno a los propios jesuítas, el de san Felipe era continuo y muy popular prácticamente desde el día de su tránsito (Francesco ZAZZERA, Diario delle onoranze a San Filippo dalla morte alla canonizzazione, Quaderni dell'Oratorio, VI [1962], pp. 1-28). A pesar de todo, el cardenal Baronio (oratoriano) estaba decidido a promover la devoción al fundador de la Compañía, incluso con gestos ostensiblemente forzados, como agarrar una escalera y subirse en ella para colgar un lienzo con su retrato sobre su sepultura a la vista de los fieles que llenaban la iglesia. En contrapartida, el cardenal jesuita Roberto Bellarmino, frente a posturas más extremas y condenatorias que se daban sobre todo entre los miembros del Santo Oficio, sostenía la legitimidad del culto al fundador del Oratorio, a pesar de algunas extralimitaciones del culto popular. Vide GOTOR, Il beati del Papa, pp. 48-65. Sobre el importante papel desempeñado por la iconografía en la promoción del culto: Ruth S. NOYES, On the Fringes of Center: Disputed Hagiographic Imagery and the Crisis over the Beati moderni in Rome ca. 1600, en Renaissance Quarterly, 64/3 (2011), pp. 800-846.

10 Alfonso ManZANEDO, Compendio della vita della serafica vergine S. Teresa di Giesu, gloria dell'antica Religione della Madonna del Carmine e Fondatrice de Padri e Monache Scalze del medemo Ordine, Per Vitale Mascardi, Roma, 1647. 
Con todas estas medidas, quedaba ya para siempre concentrada en la figura del Papa toda la capacidad reguladora y sancionadora del reconocimiento de la santidad que, lentamente, durante la Edad Media, se había ido transfiriendo (como tantas otras competencias) desde la jurisdicción episcopal. El pontífice delega, a su vez, dicha competencia exclusiva en la Congregación de Ritos. Se refuerza, de este modo, el proceso de centralización romana y, a partir de este momento, cualquier gestión relacionada con el reconocimiento oficial de la santidad tendrá como única sede la Curia Romana.

Felipe II se percató de la importancia de contar con santos españoles canonizados por el Papa ${ }^{11}$. No era lógico que la Iglesia española, con tanta historia y con la energía desplegada lo mismo en el concilio de Trento que en la evangelización americana, dispusiera de tan escaso número de santos inscritos en el calendario universal. Movido por la especial devoción que el monarca profesaba al franciscano fray Diego de Alcalá (San Nicolás del Puerto, 1400 - Alcalá de Henares, 1463), al que atribuía la curación milagrosa de su hijo el príncipe Carlos, decidió promover su canonización. No fueron sencillas las gestiones y Sixto V fue forzando la situación cada vez más hasta que, tras asegurarse el apoyo de Felipe II a la invasión de Inglaterra con la famosa Armada Invencible, finalmente accedió a canonizar al fraile. La ceremonia tuvo lugar en San Pedro el 10 de julio de 1588, resultando de gran brillantez pues no se escatimó en gastos ${ }^{12}$. Detrás de él vendrían muchos más, porque como ponía de relieve el auditor Francisco Peña:

De muchas gracias y divinos favores ha colmado el Cielo a la gloriosa y afortunada España, por lo que se siente infinitamente obligada al Señor; mas de ninguna [gracia] hace mayor estima, ni reputa como de mayor beneficio, que de verse todavía en esta edad y tiempo favorecida de la divina misericordia con hombres santos que, naciendo en ella y ejercitándose en toda clase de virtudes, y vida santa y pura, adquieren tanta gracia y en grado tanto que vienen a ser merecedores en la Iglesia Católica Romana de los supremos honores, siendo canonizados y propuestos al pueblo cristiano como ejemplo a imitar en toda santa acción y como intercesores en el cielo para aquellos que piadosamente recurren a ellos ${ }^{13}$.

11 Miguel GOTOR, Le canonizzazioni dei santi spagnoli nella Roma barocca, en Carlos José HeRNANDO SÁNCHEZ (coord.), Roma y España un crisol de la cultura europea en la Edad Moderna, vol. 2, Sociedad Estatal para la Acción Cultural Exterior, Madrid, 2007, pp. 621-629. Entre otras razones del éxito de las causas españolas, Gotor señala con acierto la influencia de los rotales españoles y la presteza y competencia con que los promotores de las causas se adaptaron a las disposiciones de la nueva Congregación de Ritos.

12 Dandelet, Celestiali eroi, pp. 183-192.

13 Canonizatione di S. Diego di Alcalá... descritta dal Dottor Francesco Pegna, en Di S. Diego de S. Nicolo del Puerto, o, de Alcala di Henares, dell'ordine di S. Franc. dell'Osseruanza, Per Francesco Zannetti, Roma 1588, p. 3: «Di molte gratie \& diuini fauori, ha colmo il Cielo la gloriosa \& fortunata Spa- 
De pronto, se manifestó una gran urgencia por verlos a todos en los altares. Y, en este sentido, Clemente VIII se quejaba en 1599 al embajador duque de Sessa: «A todos los santos de España queréis canonizar» ${ }^{14}$. Menos de dos años después, el 24 de abril de 1601, dicho pontífice canonizaba al dominico Raimundo de Peñafort, fallecido en 1275 , cuya causa aunque era antigua se había visto impulsada recientemente por la Orden de Predicadores y la Corte de Madrid; y, de igual modo, beatificaba al agustino Juan de Sahagún el 19 de junio siguiente.

Tanto durante el reinado de Felipe II como en el de sus sucesores, las relaciones con la Santa Sede atravesaron momentos de mayor o menor cercanía. Algunos pontífices sintonizaron mejor que otros con los monarcas de la casa de Austria y con los intereses políticos de la Corona española. Esta sintonía tuvo también un reflejo en la promoción de nuevos beatos y santos, si bien los papas normalmente se mostraron reacios a las prisas con las que se pretendía llevar adelante asuntos $\tan$ graves.

\section{UNA CANONIZACIÓN PREPARADA, EN PRINCIPIO, SOLO PARA SAN ISIDRO}

Uno de los papas más cercanos a los intereses hispanos fue, sin duda, Paulo V (Camilo Borghese), bajo cuyo pontificado, comprendido entre 1605 y 1621, prosperaron mucho las causas de santidad españolas. Beatificó nada menos que a ocho oriundos de los reinos de España: al franciscano Salvador de Orta (5/2/1606); al dominico Luis Bertrán (19/7/1608); al fundador de la Compañía de Jesús, Ignacio de Loyola (27/7/1609); a la Madre Teresa de Jesús (24/4/1614); al arzobispo de Valencia, el fraile agustino Tomás de Villanueva (7/10/1618); al lego franciscano Pascual Baylon (29/10/1618); al patrón de Madrid, el labrador Isidro (14/6/1619), y al misionero jesuita Francisco Javier (24/10/1619). Por su parte, Felipe Neri -iniciador de la Congregación del Oratorio- había sido beatificado el 11 de mayo de 1615. De los trece beatos reconocidos durante el pontificado de Paulo V, ocho eran españoles. Frente a este abultado número de beatificaciones, solo efectuó dos canonizaciones,

gna; onde infinitamente obligata si sente al Sig. Iddio; ma di nissuna più stima fa, ne di maggior beneficio reputa, che ve dersi tuttauia in ogni età \& tempo, fauorita dalla diuina misericordia con huomini Santi che, nascendo in essa \& essercitandosi in ogni virtù \& vita santa, \& pura, acquistino tanta gratia, \& grado, che vengano à meritare nella Catholica Romana Chiesa li supremi honori, essendo canonizati, \& proposti al Christiano popolo per essempio da imitare in ogni santa attione, \& per intercesori in Cielo, per quelli che a loro piamente ricorrono».

14 Archivo de la Villa de Madrid, 2-285-2 (18/10/1599). Cit. por María José del RIO BARREDO, Literatura y ritual en la creación de una identidad urbana: Isidro, patrón de Madrid, en Edad de Oro, XVII (1998), p. 156: «Tutti li santi de Ispania boleti canoniçare». 
las de santa Francisca Romana (29/5/1608) y san Carlos Borromeo (1/11/1610), quien -por cierto- también había sido súbdito del rey de España, como hacía constar oportunamente Felipe $\mathrm{III}^{15}$.

Inmediatamente después de la beatificación de los bienaventurados Ignacio de Loyola, Teresa de Jesús, Felipe Neri, Isidro labrador y Francisco Javier, los actores de las diferentes causas comenzaron a preparar su canonización que, todos, pretendían fuera inmediata. En el fondo, no se trataba de otra cosa que de volver a presentar los procesos realizados para la beatificación, con el fin de que fueran de nuevo examinados, y añadir lo correspondiente al culto subsecuente y los nuevos milagros obrados. En este sentido, no todas las causas se hallaban en el mismo estado pues las de los beatos Isidro, Francisco Javier y Felipe contaban con la relatio realizada por los tres auditores de la Rota, pero no así Ignacio y Teresa, a pesar de que el proceso de esta última había sido tan exhaustivo que en la Curia se pensó que sería difícil presentar algo mejor y que, tal como estaba, no solo era suficiente para su beatificación sino, «en verdad, también para su solemne canonización y adscripción al número de los Santos, en la forma acostumbrada por la Iglesia $\gg^{16}$. Por tanto, comenzaron las gestiones para las declaraciones de testigos en los diversos lugares donde habían residido los beatos y donde se habían obrado los milagros. De Ávila o Madrid hasta Goa y el Japón, los promotores volvieron a construir los procesos con la clara conciencia de estar reduplicando un trabajo ya hecho pero con la pretensión de aquilatar al máximo el rigor del procedimiento, y también para recoger los nuevos milagros efectuados con posterioridad a la canonización.

De esta forma, los carmelitas descalzos abrían en octubre de 1609 el proceso romano para la canonización de Teresa, siendo asignado como Relator el cardenal Panfilii. Las gestiones fueron apoyadas por numerosas peticiones, «con cartas e instancias hechas tanto por el Emperador y el Rey Católico como por todo el Reino de Castilla, y muchos arzobispos y obispos del mismo reino» solicitando la canonización. En 1617 el Papa concedía que pudiera celebrarse su fiesta en todas las iglesias de los reinos de Castilla y Portuga ${ }^{17}$ al tiempo que las Cortes votaban a la nueva beata como compatrona junto al apóstol Santiago ${ }^{18}$. Luego se sumaron otras

15 Angelo TURCHINI, La fabbrica di un Santo, p. 16.

16 Acta Sanctorum, Octobris VII, 15-16, Typis Alphonso Greuse, Bruxelles 1845, p. 375: «verum etiam ad illius solemnem canonizationem et adscriptionem in numerum Sanctorum, in forma Ecclesiae consueta».

17 ACCS, Decreta Servorum Dei, I, pp. 50-52, 136ss, 144-145.

18 Erin Kathleen Rowe, Saint and Nation: Santiago, Teresa of Avila, and Plural Identities in Early Modern Spain, The Pennsylvania State University Press, University Park, Penn, 2011; St. Teresa and Olivares: Patron Sainthood, Royal Favorites, and the Politics of Plurality in Seventeenth-Century Spain, en The Sixteenth Century Fournal, 37/3 (2006), pp. 721-737. 
peticiones, como la del emperador Fernando II de Austria, gestionada por el padre Domingo de Jesús María Ruzzola ${ }^{19}$.

La canonización del fundador de la Compañía de Jesús fue demandada también de modo inmediato a su beatificación ${ }^{20}$. El 6 de diciembre de 1609, Martín Brenner, obispo de Graz, en Austria, suplicaba al Papa que canonizara al «fortissimum Christi athletam» Ignacio de Loyola, «cuyas oraciones y méritos, no ha de dudarse, son en beneficio de la Iglesia Católica, de modo especial en estas tierras donde su Compañía de religiosos trabaja de manera insigne para propagar la fe y la gloria de Cristo», siendo así que «todo el mundo desea ver refrendada su santidad» ${ }^{21}$. Poco después, en febrero de 1610, se unía a la petición la provincia de Guipúzcoa, que solicitaba al Papa la colocase bajo su patronazgo y procediese a su pronta canonización. Otras muchas peticiones llegaban a Roma, incluidas las del rey Felipe III, a las que se unirían también las del emperador Fernando y, de modo singular, las del monarca francés Luis $\mathrm{XIII}^{22}$. Todo ello envuelto en un enrarecido clima en el que aparecían de fondo estrategias políticas (el apoyo de la Compañía a la absolución de Enrique IV se recompensó con su retorno a Francia, de donde había sido expulsada en 1594) y una redefinición de la identidad de la propia institución, en la que se estaba intentando -por deseo expreso del Papa- minimizar la influencia de la facción hispana representada por el P. Ribadeneyra, al tiempo que se potenciaba la italiana ${ }^{23}$.

Sin que se sepa a ciencia cierta el motivo, Paulo V había manifestado en 1615 que no procedería a ninguna otra canonización ${ }^{24}$, a pesar de que había causas muy adelantadas y de que no faltaron presiones poderosas, especialmente de los jesuitas

19 Joannes Caramuelis, Dominicus. Hoc Est, Venerabilis P. Dominici a Fesu-Maria, Parthenii Ordinis Carmelit. Excalceat. Generalis, Virtutes, Labores, Prodigia, Ecstases, Et Revelationes Quibus Lectorum Instituitur Ingenium, Et Voluntas Formatur; Est Opus Universis Ascetis \& Contemplativis.., Cosmerovius, Viennae in Austria, 1655, pp. 385ss. Silvano GIORDANO, Domenico di Gesù Maria Ruzola (1559-1630). Un carmelitano scalzo tra politica e riforma nella chiesa post-tridentina, Institutum Historicum Teresianum, Roma, 1991, p. 209.

20 Pedro de Ribadeneyra, Relacion de lo que ha sucedido en el negocio de la Canonizacion del bienaventurado P. Ignacio de Loyola, fundador de la Religion de la Compañia de Fesus. Y de lo que acerca de su beatificacion ha hecho la Santidad de nuestro señor Paulo Papa V este año de 1609, Madrid, 1609.

21 Monumenta Ignatiana, ex autographis vel ex antiquioribus exemplis collecta, serie IV, II, Madrid 1918, pp. 956-958: «cuius precibus et meritis non est dubium quin ecclesia catholica, máxime in his terris ubi eius Societatis religiosi pro Christi fide atque gloria propaganda insigniter laborant... eiusque sanctitatem toti orbi testatam facere uelit».

22 Monumenta Ignatiana, serie IV, II, pp. 958-960, 962-967, 978-979.

23 José MARTínez Millán, Transformación y crisis de la Compañia de fesús (1578-1594), en Flavio RURALE (coord.), I religiosi a corte. Teologia, politica e diplomazia in Antico regime, Bulzoni, Roma, 1998, pp. 101-125; Sabina PAVONE, I gesuiti dalle origini alla soppressione, Laterza, Bari-Roma, 2013, pp. 33-44.

24 AGS, Estado, leg. 1001, n ${ }^{\circ}$ 16: Francisco de Castro a Felipe III (Roma, 10/4/1615). 
que querían ver pronto canonizado a su fundador, al igual que los carmelitas descalzos a la beata Teresa.

Por lo que respecta a la causa del beato Isidro, sus promotores tampoco descansaron a pesar de verlo ya oficialmente elevado a los altares. Su caso era verdaderamente singular puesto que había recibido culto desde antiguo como santo, aunque sin el reconocimiento de Roma ${ }^{25}$. Con la instalación de la Corte en Madrid, su figura había adquirido nueva dimensión y no parecía bien que el patrón de la capital careciera del estatus oficial de la santidad, por lo que tanto sus munícipes como la propia Casa Real se implicaron con energia en la promoción de la causa (incluso durante la translación de la Corte a Valladolid de 1601 a 1609). En primer lugar, se instruyó el proceso de beatificación, basado en la biografía antigua y, sobre todo, en el culto constante y la multiplicidad de milagros que se le atribuían. Resuelto éste favorablemente ${ }^{26}$, no cabía ya sino reiterar las demandas hasta la consecución de la canonización propiamente dicha.

Felipe III enviaba una carta al papa en febrero de 1620 solicitando la canonización, que se unía a la súplica de la villa de Madrid, que había desplazado ex profeso a Roma un agente, Diego de Barrionuevo y Peralta, para concluir con éxito y lo antes posible la causa. La respuesta del pontífice no fue alentadora pues, según comunicaba éste, Paulo V le había dicho «que se contentasen con la beatificación» ${ }^{27}$. Pero, lo cierto es que pronto cambió de opinión, esperando del rey de España que advirtiera su benevolencia y «se sirviese de honrar la Casa Burghesa mandando cubrir al Príncipe de Sulmona», es decir, elevar al rango de grande de España a su sobrino Marcantonio Borghese. Felipe III accedió a la petición, como se comunicó a Roma por conducto diplomático ${ }^{28}$. El 6 de octubre de 1620, encontrándose en Frascati,

25 María José Del Rio BARREDO, Agiografia e cronaca di una capitale incerta (Madrid e Isidro Labrador, 1590-1620), en Giovanna FIUME (ed.), Il santo patrono, pp. 45-67.

26 ACCS, Decreta Servorum Dei, I, pp. 155-156. El 2 de mayo de 1619, el cardenal Lancellotti presenta la causa del siervo de Dios Isidoro labrador de Madrid ante la Congregación. «Re matura discussa..., frequentia populi ad sepulchrum, ac demum de veneratione ac corporis praedicti Servi Dei Isidori», se propone su beatificación al Papa y que se celebre «die 15 maii (quo dies festus ejus translationis celebrabitur) in Regni Hispaniarum, Portugalliae et Algarbiorum, nec non Indiarum tan orientalium quam occidentalium; Matritii vero dumlascat ritu duplici et cum octava, tamquam de Patrono». «Facto verbo cum Ssmo D. N. Sanctitas Sua Sacrae Cong. Sententiam comprobavit».

27 AGS, Estado, leg. 1867: Sobre lo que ha escrito don Diego de Barrionuevo en la inclusa carta tocante a la canonización de Isidro (9/2/1619).

28 Las gestiones para la concesión en AGS, Estado, leg. 2994, Consejo de Estado (5/11/1620). El 29 de diciembre de 1620 Scipione Borghese agradecía a Felipe III la gracia concedida a su sobrino Marcantonio, Príncipe de Sulmona, «benigna dimostrazione stimata da noi infinitamente». AAV, Fondo Borghese, serie II, 422, 387v-388. No tiene nada de extraño esta petición en un pontificado como el de Paulo V, en el que el nepotismo volvió a recuperar la fuerza de antaño, persiguiendo el engrandecimiento de su familia. 
el cardenal nepote, Scipione Borghese, comunicaba al monarca a través del nuncio Francesco Cennini que Su Santidad

perseverando en la misma benigna disposición hacia Su Majestad, ha resuelto querer complacerla también con la canonización del beato Isidro, tan deseada por Su Majestad, a pesar de que Su Beatitud había determinado firmemente no proceder a ninguna otra canonización después de las dos que ha hecho, con el aplauso general, y por eso ya había dado su negativa a diversas peticiones importantísimas para canonizar a fundadores de religiones [órdenes religiosas] y para otros beatos, hechas y reiteradas particularmente por los padres jesuítas.

Todas estas circunstancias «cualifican la gracia y muestran claramente el amor paterno que Su Santidad profesa a Su Majestad $»^{29}$.

La maquinaria se puso en marcha y en noviembre de 1620 se presentaba la instancia para la canonización del beato Isidro ${ }^{30}$. Fue nombrado relator el cardenal Lancelloti pero falleció, por lo que se designó al cardenal Muto. La causa fue rápida, entre otros motivos, por los apremios que recurrentemente realizaba el cardenal nepote $^{31}$. Pero Paulo V fallecía en el palacio del Quirinal el 18 de enero de 1621.

El 9 de febrero siguiente, el cónclave elegía papa al cardenal Alessandro Ludovisi, que tomó el nombre de Gregorio XV. El nuevo pontífice resultó ser también un antiguo aliado de los intereses españoles y pronto manifestó su propósito de continuar adelante con la canonización del beato Isidro, que el rey Felipe III había solicitado de nuevo, y por última vez, antes de fallecer el 31 de marzo de ese mismo año. Su hijo, Felipe IV insistió igualmente en la urgencia de la glorificación. Tras subsanar un defecto de forma (ya que solo habían sido nombrados en el proceso remisorial de Madrid dos jueces, en lugar de tres), en la Congregación del 8 de mayo de 1621 se aprobaba el proceso sobre la santidad de vida in genere y los memoriales de los tres auditores de la Rota que certificaron la heroicidad de las virtudes teologales y cardinales. En la sesión del 29 de mayo comenzaba la validación de los milagros, tres realizados en vida y otros tres después de muerto. Buena prueba del interés que tenía el nuevo Papa para proceder de manera urgente a la canonización del beato

29 AAV, Fondo Borghese, serie II, 422, c. 180 (6/10/1620): «Perseverando nella medesima benigna dispositione verso la Maestà Sua, ha risoluto di voler compiacerla, anche nella canonizatione del Beato Isidro, tanto desiderata da la Sua Maestà, contuttoche sua B(eatutidi)ne havesse fermamente determinato di non venir più ad altre canonization, dopo le due che ha fatti, con aplauso tanto generale, et havesse perció data la negativa a diverse instanzie grand(issim)e per fondatori di Religioni, e per altri Beati, fatti e reiterati particularmente da i Padri Gesuiti... qualificano la gratia e mostrano chiaramente l'amor paterno di Sua San(ti)tà verso la Maestà Sua».

30 ACCS, Decreta Servorum Dei, I, pp. 168-171.

31 ACCS, Decreta Congregationis Sacrorum Rituum (1610-1621), ff. 159v-160, 192 y v, 230-233. 
Isidro es la instancia que hizo al procurador de la villa de Madrid, Barrionuevo, para que se diera «prisa... para hacer la fiesta», es decir, para tener preparado el theatrum sacrum, un magno escenario efímero que se instalaba en la cabecera de la basílica de san Pedro para realizar la ceremonia de canonización, cuyas obras se habían iniciado en el mes de julio ${ }^{32}$.

Precisamente, en la sesión de la Congregación celebrada el 10 de julio se aprobaban los milagros para la canonización del beato Isidro y la causa quedaba concluida a falta de que el Papa procediera a fijar la fecha ${ }^{33}$. Ese mismo día se iniciaron las gestiones pertinentes para la canonización del beato Francisco Javier, nombrándose relator al cardenal Sagrato, quien también apoyaría decididamente la causa del beato Ignacio, hasta lograr llevarlas a término ${ }^{34}$. Para ello contaron con el apoyo explícito del joven rey de Francia Luis XIII, que en una carta autógrafa remitida a Gregorio XV con ocasión del inicio de su pontificado, se mostraba muy agradecido por la educación recibida de la Compañía de Jesús y, dado que

el proceso de canonización del bienaventurado Ignacio, fundador de dicha orden, está concluido y que no resta sino que Vuestra Santidad queráis concluir la obra buena, tengo a bien suplicar [la canonización]... Espero conseguir nuevas bendiciones [de Dios] si Vuestra Santidad concede que, a mi súplica, sea canonizado ${ }^{35}$.

A comienzos del verano de 1621 ya era público que el Papa iba a canonizar al beato Isidro; por ello, jesuítas y carmelitas reduplicaron sus esfuerzos para alcanzar igualmente la canonización de sus fundadores implicando a todos aquellos que podían hacer fuerza. El 8 de julio la duquesa de Alburquerque, esposa del embajador del rey de España, y la duquesa de Fiano, cuñada de Gregorio XV, le suplicaron encarecidamente que acelerara la canonización de la beata Teresa, respondiéndoles: «Todo el mundo clama por esta Santa; en verdad es grande la Santa. No podemos resistir ya más; lo haremos, lo haremos» ${ }^{36}$.

Mientras tanto ya se hablaba de la forma más conveniente de realizar tantas canonizaciones como se preveía que tendría lugar próximamente (pues también estaban muy avanzadas las causas de los beatos Luis Bertrán y Tomás de Villanueva);

32 ACCS, Decreta Congregationis Sacrorum Rituum (1610-1621), ff. 241 y v., 243, 246-248, 256-257.

33 ACCS, Decreta Servorum Dei, I, p. 182.

34 ACCS, Decreta Servorum Dei, I, p. 181.

35 BAV, Boncompagni Ludovisi, E. 79, ff. 248-249v: «le procese de la canonisation du bienheureux Ignace, instituteur du dit ordre, estoit fait, et qui'l, ne reste plus que le vouloir de V(ostre) S(ainti)té á parfaire ce bon oeuvre, j'ay bien voulu la supplier (...) J'espere de nouvelles bénédictions, si $\mathrm{V}$ (ostre) S(ainti)té octroye qu'á ma priéie il soit tost canonisé».

36 BNE, ms. 2232, f. 83: «Tutto il mondo esclama per questa Santa; veramente è grande la Santa. Non potemo gia più resistire, lo faremo, lo faremo». 
algunos pensaban que lo mejor sería efectuarlas individualmente, como era costumbre, pero otros apostaban por hacerlas de dos en dos en una sola ceremonia. Más aún, en junio de 1621 el embajador del emperador Fernando II ante la Santa Sede, Savelli, ya había propuesto al cardenal Ludovico Ludovisi, nepote del Papa, la celebración de una canonización acumulativa, si bien éste no le dio mayores esperanzas indicándole únicamente que le haría llegar la idea a su tío ${ }^{37}$.

De cualquier forma, las cosas avanzaban de tal modo que, todavía a comienzos de noviembre lo único que parecía seguro era la canonización de Isidro; de hecho, el día 13 se aprobaban las oraciones que se utilizarían en la ceremonia ${ }^{38}$. Por su parte, el comisionado de Madrid, Diego de Barrionuevo, confiaba en que la ceremonia sería exclusiva para el patrón de la Villa y Corte, y en este sentido se había concertado con Paolo Guidotti Borghese el gran aparato escénico que, en buena parte, estaba ya construido.

Pero las presiones en otro sentido eran muchas, procedentes en su mayoría de jesuítas y carmelitas descalzos, que ansiaban ver canonizados cuanto antes a sus santos. Siendo así que el proceso ya estaba concluido ${ }^{39}$ y con la predisposición favorable que Gregorio XV había manifestado a la embajadora española y a su propia cuñada, el carmelita P. Domingo Ruzola, prior del convento de la Scala y superior de la descalcez italiana, hombre muy cercano al Papa, reduplicó sus esfuerzos para hacerle ver la conveniencia de canonizar a la beata Teresa y, al fin, consiguió de éste su deseo: «Canonizaremos a la beata Madre junto con el beato Isidro». Por tanto, parece que la primera incorporación a la magna canonización tras el beato Isidro fue la de la beata Teresa. Podía sentirse satisfecho el P. Ruzzola.

No gustó nada a Barrionuevo la incorporación de la santa abulense, que restaría protagonismo al labrador madrileño en cuya causa venía trabajando denodadamente. Y resistió cuanto pudo. El cronista carmelitano fray Joseph de Santa Teresa relata lo sucedido:

Determinado ya Su Santidad con la luz de el Cielo de canonizar a nuestra Santa Madre primero que a otros, cuyas causas estaban tambien concluidas, embarazaron sus agentes la nuestra, especialmente don Diego de Barrionuevo, cavallero del Orden de Santiago, y procurador de la Real Villa de Madrid por la canonizacion de san Isidro, su patrón. Y aunque Su Santidad en el Breve que trae el ilus-

37 KAISER-HOF-UND STAATSARCHIV (Viena), Rom, Korrespondenz, 49, 404r-403r. Savelli a Ferdinando II, Roma 12/6/1621. Cit. por GIORDANO, Domenico di Gesù Maria Ruzola (1559-1630), p. 209.

38 ACCS, Decreta Servorum Dei, I, p. 197.

39 Beatae virginis Teresine vitae, virtutum, ac miraculorum relationes SS.D.N. Paulo papae V per Sacrae Rotae auditores deputatos factae ad solemnem canonizationem, Barcinonae, apud S. Liberôs, 1621. 
tríssimo Caramuel ofreció que canonizaría juntamente a los dos, hizo tales instancias don Diego porque saliese antes y solo San Isidro, alegando varias razones de estado, que a vezes ni a los santos suelen perdonar, que encontrándole un día nuestro milagroso padre fray Domingo de Jesús María, venerado del Pontífice, y de todas las naciones, le dixo con animosa entereza: «Señor don Diego, no se han de tratar las cosas celestiales como las pretensiones de la tierra, ni las razones políticas con que v. md. camina en su pretensión, tienen lugar ni fuerza con los santos, dexe v. md. en paz a santa Teresa, no quiera oponerse, ni retardar la gloria que la Iglesia le previene, que a pesar de sus embarazos se han de canonizar los dos santos en un día; y advierta que sabrá Dios castigar a quien persigue (aunque sea con sobreescrito de piedad) a una santa que tan bien merecidos tiene estos honores». Estas palasbras, nacidas de aquel milagroso corazón así corrigieron al noble procurador, que dexó su pretensión en manos del V. P. fray Domingo ${ }^{40}$.

Vencida la resistencia de Barrionuevo, Ruzzola consiguió también la licencia papal para comenzar los preparativos necesarios para la canonización de la Santa Madre junto con el beato Isidro ${ }^{41}$.

Pero al tratarse ya de dos canonizaciones comenzaron a plantearse problemas de precedencia. Los devotos de la reformadora carmelitana, al menos algunos, entendían que debía ocupar el primer lugar. Por una carta fechada el 21 de noviembre, que implícitamente corrobora el relato anterior, podemos saber que el duque de Alba, Antonio Alvárez de Toledo, habiéndose enterado por las carmelitas de que su fundadora iba a ser canonizada junto con el beato Isidro y en segundo lugar, rogaba a la gran duquesa de Toscana, María Magdalena de Austria, que intercediera ante Gregorio XV para que no permitiera semejante cosa en atención «a los méritos de sancta Theressa» ${ }^{42}$.

40 José de SANTA Teresa, OCD, Reforma de los Descalzos de Nuestra Señora del Carmen de la primitiva observancia hecha por santa Teresa de Jesús en la antiquíssima Religión, fundada por el gran Profeta Elías, t. IV, Por Jualián de Paredes, impresor de libros, Madrid, 1684, p. 312.

41 Caramuelis, Dominicus. Hoc Est, 388 y José de SANTa Teresa, loc. cit. (traducción del texto latino al castellano): El P. fray Domingo «mostrando que en su obrar le movía la honra de Dios, y no la propia, hizo instancia al Pontífice para que con santa Teresa y san Isidro canonizase a las dos grandes lumbreras de la sagrada religión de la Compañía de Jesús, facilitando algunos estorvos que retardaban sus causas: lo qual sabido de los padres del Oratorio, le suplicaron que hablase tambien por su santo fundador Felipe Neri para que a todos cinco los canonizase en un día. Pudo tanto con Su Santidad el V. P. (que por esta causa le llamaban para con Gregorio el Omnipotente) que le concedió quanto en esta pretensión le suplicaba». Si se atiende a estas fuentes, parecería que el P. Ruzzola fue quien consiguió del papa Gregorio XV la agregación de los otros cuatro nuevos santos a la canonización ya pactada del beato Isidro.

42 ARCHIVIO DI STATO, Florencia, Mediceo del Principato 5080, f. 83 (21(11/1621). Cit por Clare COPELAND, Spanish Saints in Counter-Reformation Italy, en Piers BAKER-BATES y Miles PATTENDEN (eds.), The Spanish Presence in Sixteenth-Century Italy: Images of Iberia, Farnham, 2015, p. 110: «Canonizaremo la Beata Madre Teresa di Giesu insieme col Beato Isidoro». 
Mientras tanto, se hablaba ya de incluir también al beato Ignacio, aprovechando la coyuntura favorable de ocupar Gregorio XV el trono de san Pedro ${ }^{43}$. Para urgir su canonización habían ido llegando a Roma durante el mes de septiembre peticiones procedentes de altas personalidades como la archiduquesa Isabel, infanta viuda de España, el duque Maximiliano de Baviera, y de monsieur de la Modène en nombre de Luis XIII. A los tres respondió el Pontífice que, por encima de todo, en negocio tan grave deseaba secundar al Espíritu Santo y para eso necesitaba alguna moción que le hiciera ver claro. Resulta interesante comprobar la insistencia de Gregorio XV en este punto: antes de proceder a la canonización, debe estar seguro de que esa era la voluntad de Dios, para lo que que pide la oración de quienes la demandan:

Pero, de igual forma, no ignora Su Excelencia que los hombres preclaros por su santidad, de quienes se cree que su virtud les ha llevado al cielo, sin embargo no han de ser venerados en los altares y en los templos antes de que, habiéndolo meditado con sosiego y estando seguros de que así lo dicta el Espíritu Santo, no lo autoricen los Sumos Pontífices. Por tanto, en tan grave asunto no debemos obedecer a ninguna potestad humana sino al mandato divino, quienes hemos sido constituidos por Dios como sus vicarios en la cima de la autoridad apostólica. Y eso es en definitiva, lo que pediremos humilde y confiadamente en nuestras oraciones a Aquel que nos puede mostrar su decisión y nos puede convencer para tomar la nuestra. Así será todo tanto más beneficioso para la religión católica como agradable a su Cristianísima Majestad, e igualmente a su Excelencia, que tanto esfuerzo ha empleado en postular la glorificación de estos santos varones ${ }^{44}$.

De forma parecida responde tanto al duque de Baviera, que también había solicitado la canonización del beato Felipe Neri, como a los electos de Nápoles. Gregorio XV les hace ver que nada le agradaría más, pero necesita una señal del cielo:

Nos ciertamente deseamos también enaltecer con esta clase de honores y al máximo, la gloria de aquel varón a quien Roma, no hace mucho tiempo, contem-

43 Anthony D. WRIGHT, «La sua santità non inclina niente»: The Papacy and the Canonization of Ignatius Loyola, en Thomas M. McCoog (ed.), Ite inflammate omnia. Selected historical papers from conferences held at Loyola and Rome in 2006, Institutum historicum Societatis Iesu, Roma, 2010, pp. 441455.

44 AAV, Arm XLV, 22, f. 175 y v.; BV, Boncompagni, E. 69, ff. 198 y v: «Sed enimvero non ignorat Nobilitas tua homines sanctitate praecipuos, quos virtus coelo intulisse creditur, aris templisque non prius colendos esse, quam rediutius pensitata, et Spiritu Sancto dictante ad id decernendum Pontifices Maximi impellamur: tanta enim in re Divino Imperio, non humanae authoritati obsequi debemus, qui Vicariam Deo operam in Apostholicae dignitatis fastigio praestamus. Quod igitur in Nobis est, suppliciter, demisseque ipsum orabimus, ut suam Nobis sententiam patefaciat, atque id Nos decernere suadeat, quod sit et Catholicae Religioni salutare, et Christianissimae et Maiestati gratissimum, Nobilitatem vero tuam, quae tanto studio sanctos viros gloriae suffragatur». 
pló como astro deslumbrante de santidad, que iluminaba esta época tenebrosa; y sin embargo, necesitamos que el Espíritu Santo nos persuada a ello antes de tomar la decisión en un negocio tan grave ${ }^{45}$.

Cierto es que el Pontífice se había referido, en una carta dirigida a la archiduquesa Isabel, con fecha del 22 de octubre, a «dificultades no leves que lo impedirían», pero por el contexto parece referirse, más que nada, a la celebración conjunta de las canonizaciones ${ }^{46}$. Que ya se había considerado dicha posibilidad, al menos en las cancillerías europeas, o que se había difundido de modo interesado el bulo, lo corrobora una carta remitida pocos días después, el 1 de noviembre, por el rey Felipe IV al Papa:

Holgaré de que en caso que la declaración de la canonización de los cuatro santos, que ahora ha de hacer Vuestra Beatitud, no pueda ser de todos juntos, sino de dos en dos, se canonice la santa madre Teresa de Jesús en compañía del glorioso san Isidro, por el gran consuelo y satisfacción que de ello resultará a todos estos reinos ${ }^{47}$.

Probablemente, para cuando llegó la petición regia a Roma, Gregorio XV ya había visto con claridad la pertinencia de proceder a la canonización inmediata no solo del beato Ignacio sino también del beato Francisco Javier ${ }^{48}$. Gregorio XV guardaba un gran afecto a la Compañía de Jesús pues, entre otras razones, había sido antiguo alumno del Colegio Germánico-Hungárico y, luego, del Romano. No resulta, por tanto, extraña la inclusión del beato Ignacio ni tampoco la del beato Javier, mucho menos aún si se tiene en cuenta la inquietud por la labor misionera que le animaba, concretada en la erección de la Congregación de Propaganda Fide en 1622, coincidiendo prácticamente con la canonización. Al incluir al gran misionero Francisco Javier, Gregorio XV proponía un modelo para quienes habrían de continuar la tarea de la expansión de la fe entre los infieles.

Cabe suponer que fue a finales de octubre o comienzos de noviembre de 1621 cuando Gregorio XV decidió la canonización conjunta de los cuatro beatos españoles, si bien por una razón estratégica de carácter político-diplomático no lo comunicó hasta pasado un mes. Desde comienzos de diciembre fueron despachándose

45 AAV, Arm XLV, 22, f. 176v; BV, Boncompagni, E. 69, ff. 199-201: «Nos quidem eius viri gloria, quem Roma clarissimum sanctimonia sydus huius aetatis tenebris illuxisse non ita pridem aspexit, eo etiam honoris genere augeri maximopere cupimus: tamen Spiritus Sanctus Nos admoneat, necesse est, antequam quicquam in tam gravi negotio decernatur».

46 AAV, Arm XLV, 22, f. 207: «difficultatibus non levibus impediri videmus».

47 AHN, AMAE, Santa Sede, legajo 21, n. 321 (Felipe IV a Gregorio XV, 1 de noviembre de 1621).

48 BAV, Boncompagni, E. 69, f. 295. 
cartas en las que se comunicaba de manera individual a los patrocinadores regios, la decisión de canonizarlos ${ }^{49}$. El 22 de diciembre salieron cartas para la infanta sor Margarita de la Cruz y para el cardenal infante don Fernando comunicando también la beatificación de fray Pedro de Alcántara ${ }^{50}$.

¿Cúal fue el motivo por el que, según parece, el Papa no quiso hacer pública su decisión de proceder a una canonización conjunta de los cuatro beatos españoles? Como se acaba de apuntar, fueron razones de carácter político-diplomático. La canonización del beato Isidro estaba en marcha, alentada por la villa de Madrid y, de forma particular, por el rey de España; el teatro efímero levantado en el corazón de la basílica de San Pedro estaba prácticamente concluido y en él todo hacía referencia al santo agricultor y a los promotores de su causa, destacando visiblemente las armas de Felipe IV. Gregorio XV no podía dar marcha atrás sobre este asunto. Pero, a la vez, se había ido comprometiendo a efectuar otras canonizaciones. Con los carmelitas, la de la Madre Teresa que, en principio, no gustó a Barrionuevo pero el rey aceptaba, a tenor de la correspondencia, como «el mal menor».

Más complicado era satisfacer la petición efectuada por el rey de Francia de canonizar al beato Ignacio de Loyola en primer lugar, como un gesto de deferencia hacia el monarca francés que lo pedía como un favor personal. Gregorio XV, a quien no le desagradaba absolutamente nada esta solicitud por el afecto que profesaba a la Compañía de Jesús, una vez que tuvo clara la conveniencia de efectuarla, hubo de discurrir el modo de llevarla a cabo. La Compañía urgía y, al igual que Luis XIII, seguía pretendiendo que fuera la primera de todas. Lo cual era ya imposible so pena de desairar al rey de España y provocar un conflicto diplomático de dimensiones imposibles de predecir. El propio soberano francés era consciente de ello y por eso peleó para conseguir el segundo lugar, pasando por encima de la beata Teresa. Por otro lado, puestos a canonizar santos españoles, el Papa agregó por su cuenta, si bien ya lo habían solicitado los jesuitas, a san Francisco Javier, con el convencimiento de que nadie podría quejarse por ello.

Con toda probabilidad, Gregorio XV con fino instinto diplomático esperó el momento oportuno en el cual todas las partes tendrían que ceder algo para alcanzar un acuerdo ante la perspectiva de quedarse al margen. Ese momento preciso se produjo a mediados de noviembre de 1621 . Felipe IV no podía negarse a la canonización de otros santos españoles, aunque estos no hubieran sido promovidos en primera

49 Resulta muy interesante el dato de que el 1 de diciembre se comunicó a Felipe IV la canonización del beato Isidro y de la beata Teresa por medio de sendas cartas. Ese mismo día se comunicaba al duque Wolfgang Guillermo del Palatinado-Neoburgo la canonización de los beatos Ignacio y Francisco.

50 AAV, Arm XLV, 19, f. 224. 
instancia por él mismo. Nadie comprendería semejante negativa por cuanto la inclusión de más santos españoles redundaba en mayor gloria para su nación de origen. Por tanto, Felipe IV, y en consecuencia, la villa de Madrid, tenían que transigir con la agregación y la consecuente relativa pérdida de protagonismo del beato Isidro.

Por otro lado, decidiendo la incorporación de los beatos Ignacio y Javier a falta de poco tiempo para la ceremonia de canonización, el Papa cumplía con su promesa al rey de Francia y, al mismo tiempo, dado que el teatro donde se llevaría a cabo estaba ya finalizado, hacía imposible no solo que Luis XIII pidiera que se levantara otro nuevo -con el consiguiente retraso (y gasto), que nadie deseaba, empezando por la Compañía de Jesús- sino tan siquiera que reclamara la ostensión de las armas de Francia, provocando el disgusto de la Corte de Madrid.

Gregorio XV dio, por tanto, con la solución idónea. Todos debían ceder para no quedarse fuera: el rey de España y la villa de Madrid transigían con la celebración de una ceremonia de canonización múltiple a cambio de conservar el primer puesto y el protagonismo escénico; el monarca francés aceptaba el status quo iconográfico y renunciaba a cualquier presencia simbólica en la celebración a cambio de hacerse presente como promotor de la causa ignaciana; la Compañía de Jesús renunciaba al primer puesto para su fundador a cambio de la certeza de una canonización inminente y un segundo puesto muy honorífico ${ }^{51}$, además del hecho doblemente gratificante de contar en el nómina con otro jesuita igualmente canonizado; y, por último, los carmelitas, sabiendo que no contaban con apoyos externos tan soberanos, aceptaban con resignación y elegancia el último lugar a cambio de no tener problemas ni con la Compañía ni con Francia en vistas a su expansión.

Resuelto el conflicto con un elaborado equilibrio diplomático, no es posible asegurar si el Papa albergaba el deseo de incluir también en dicha canonización a santo Tomás de Villanueva como se ha afirmado en alguna ocasión, siendo finalmente sustituido por san Felipe Neri.

Lo que sí resulta completamente cierto es que la inclusión del beato Felipe Neri -cuya causa había sido concluida con éxito el 13 de noviembre- fue a propuesta de la propia Congregación de Ritos con toda probabilidad para evitar una canonización exclusivamente española. El 22 de diciembre, «siendo así que el cardenal del Monte ya había referido en esta misma [sesión de la] Congregación que el propósito

51 Giuseppe Domenici, La glorificazione di Sant'Ignazio di Loyola e di San Francesco Saverio, p. 25 habla de las gestiones del rey de Francia para que el beato Ignacio «nella bolla sia nominato subito dopo il B. Isidoro sans qu'auire le puisse precèder en cette solemnité». También de las indicaciones que dio el General de los jesuitas «ut nostri loquerentur de praecedentia inter Sanctos sine ulla significatione voluntatis, ut nostri praeferrentur». Las razones por las cuales san Ignacio aparece en segundo lugar y no en el primero, como hubieran deseado sus devotos, en Acta Sanctorum, Julii VII, 29-31, Apud Jacobum du Moulin, Anturpiae 1731, p. 619. 
del Santo Padre era canonizar el mismo día a los beatos Isidro, Teresa de Jesús, Ignacio y Francisco Javier, la Sagrada Congregación se inclinó a poder incluir entre estos también al beato Felipe Neri» ${ }^{52}$.

La propuesta de incluir un quinto canonizando fue muy bien acogida por el Pontífice por cuanto, «habiendo conocido por mucho tiempo a san Felipe Neri, le guardó siempre gran afecto y devoción $»^{53}$, había ingresado en el Oratorio, del que luego llegó a ser rector, y ya cardenal, no solo seguía frecuentando la Vallicella, sino que había actuado como auditor en la última fase del proceso de su beatificación ${ }^{54}$. Solicitó, no obstante, a la Congregación que diera su parecer sobre el modo concreto de proceder a las canonizaciones, según informó a los cardenales el padre carmelita Domingo Ruzzola. El 3 de enero de 1622 la Congregación discutió sobre este punto concluyendo que lo mejor sería celebrar una sola ceremonia e incluir en ella la canonización de los cinco, en lugar de cinco ceremonias distintas separadas entre sí aunque solo fuera por poco tiempo ${ }^{55}$.

El 8 de enero de 1622 el Papa comunicaba oficialmente su decisión de canonizar a los cinco beatos conjuntamente. Poco después, el 22 de enero remitía una carta al rey Felipe IV comunicándole su decisión de canonizar «no solo a la beata Teresa y al beato Isidro en un mismo día, como Su Majestad había solicitado... sino también a aquellos dos astros no solo del cielo español sino de la Iglesia Católica y del Nuevo Mundo, los beatos Ignacio y Javier», juntamente con el beato Felipe $\mathrm{Neri}^{56}$.

52 ACCS, Decreta Servorum Dei, I, p. 202: «cum Illmus a Monte ia hoc Congregatione retulerit mentem Ssmi esse eodem die inter Sanctos ascribere B. Isidorum, B. Theresiam de Jesu, B. Ignatium, et. B. Franciscum Xaverium Sacra Congregatio inclinavit posse inter istos connumerati etiam B. Philippum Nerium».

53 ACOR, A IV 13, f. 391: «Havendo conosciuto per molto tempo San Filippo Nerio, gli portò sempre grand' affettione e divotione». La causa del beato Felipe Neri estaba concluída y las gestiones para la canonización muy avanzadas, según refiere con detalle el Diario delli atti per la Canonizatione di S. Filippo Neri, redactado por el P. Francesco Zazzera, uno de sus máximos promotores. Como las demás congregaciones, también la del Oratorio había buscado el apoyo de los soberanos. El 17/7/1621 Maximiliano de Baviera pedía al Papa la canonización con el mismo derecho que la del beato Ignacio (f. 399). A finales de octubre, los padres Zazzera y Bochi fueron a Florencia a recabar la ayuda del gran Duque de Toscana para concluir el «negotio della canonizatione» (f. 406v.).

54 VERAJA, La beatificazione, p. 54.

55 ACCS, Decreta Servorum Dei, I, pp. 203-204. Benedictus XIV, De servorum Dei beatificatione, I/1, p. 715 .

56 AAV, Arm XLV, 19, f. 254; Arm XLV, 22, f. 311v: «Non solum Beatae Theresae, atque Beato Isidoro eadem die, ut petis, coelestes honores, ac sanctos cultum decreturi sumus, sed duobus etiam B. B. Ignatio et Xaverio, non solum Hispani coeli, sed Catholicae Ecclesiae, et novi Orbis syderibus». El embajador del duque de Urbino en Roma comunica el 26 de enero de 1622 que han llegado nuevas cartas de los reyes de Francia postulando la canonización de san Ignacio, petición que «viene ad esser superflua, sendo la $\mathrm{d}^{\mathrm{a}}$ canonizatione gia resoluta di fare, insieme con quella del Beato Isidoro da Madrid, et altri nominati» (BV, Urbin. Lat., cod. 1091, f. 70). 
Fue necesaria una delicada labor diplomática para arreglar todos los extremos inherentes al hecho nunca antes visto de una ceremonia conjunta. Las delicadas sutilezas de la diplomacia ya habían determinado el orden en el que se procedería a las canonizaciones, siendo así que todos entendieron que el último incorporado quedaba también en el mismo lugar a la hora de proceder a su inscripción en el catálogo de los santos. Ahora era necesario cubrir el acuerdo forzado con un revestimiento menos pragmático y más cercano a las rúbricas litúrgicas. Apartándose del uso tradicional, finalmente se adoptó un criterio que validaba los acuerdos previos: el cronológico, conforme a la fecha de nacimiento donde no cabía discusión para el primer puesto del beato Isidro, al que seguirían Ignacio (1491), Javier (1506), Teresa (28/3/1515) y Felipe Neri (21/7/1515). En adelante, sin embargo, se utilizaría el criterio del estado eclesiástico, precediendo siempre la jerarquía, seguida por los miembros de la vida consagrada y, en último término, los laicos, rigiendo para estos dos grupos la preferencia del varón sobre la mujer y el hecho de haber sido fundador/a ${ }^{57}$.

Quedaban aún otros muchos asuntos por resolver en una ceremonia inédita. Los diversos actores impulsores de las causas comenzaron a resolver todos los detalles (tan importantes desde el punto de vista diplomático) junto con los maestros de ceremonias del Papa. Conviene indicar al respecto que aunque hubo tensiones, finalmente todos facilitaron cuanto pudieron el arreglo.

El papa fijó la fecha de la ceremonia para el sábado 12 de marzo, fiesta de san Gregorio Magno, su patrón. Dada la premura de tiempo, inmediatamente se convocaron los tres consistorios requeridos para la diligencia de las causas. El 19 de enero se celebró el consistorio secreto para la canonización de los beatos Isidro ${ }^{58}$, Ignacio ${ }^{59}$ y Javier $^{60}$, y el 24 para los beatos Teresa y Felipe Neri ${ }^{61}$, presentando el cardenal del Monte como decano de la Congregación la correspondiente relatio, que se había entregado impresa a todos los cardenales, quienes dieron su placet, juzgando que si así lo estimaba

57 Benedictus XIV, De servorum Dei beatificatione, I/1, pp. 715-716.

58 Relatio facta in consistorio secreto coram S.D.N. Gregorio papa 15. a Francisco Maria episcopo Portuensi S.R.E. card. a Monte Die 19. Ianuarij 1622. super vita, sanctitate, actis canonizatione, \& miraculis beati Isidori Agricolae de Matrito, Romæ, Apud Hæredem Bartholomæi Zannetti. Anno m.dc.xxii.

59 Relatio facta in consistorio secreto coram s.d.n. Gregorio Papa XV a Francisco Maria episcopo portvensi s.r.e. card. a Monte die xix. ianuarii m.dc.xxii. super vita, sanctitate, actis Canonizationis, \& miraculis beati Ignatii fondatoris Societarie Iesu, Romæ, Apud Hæredem Bartholomæi Zannetti. Anno m.dc.xxii.

60 Relatio facta in consistorio secreto coram S.D.N. Gregorio papa 15. a Francisco Maria episcopo Portuensi S.R.E. card. a Monte die 24. Ianuarii 1622. super vita, sanctitate, actis canonizationis, \& miraculis beati Francisci Xavier e Societate Iesu, Romæ, Apud Hæredem Bartholomæi Zannetti. Anno m.dc.xxii

61 Relatio facta in consistorio secreto coram s.d.n. Gregorio papa 15. a Francisco Maria episcopo Portuensi S.R.E. card. a Monte die 24. Ianuarij 1622. super vita, sanctitate, actis canonizationis, \& miraculis Beati Philippi Nerij Florentini Congregationis Oratorij fundatoris, Romæ, Apud Hæredem Bartholomæi Zannetti. Anno m.dc.xxii. 
oportuno, podía el Papa seguir adelante ${ }^{62}$. El consistorio público para los tres primeros se celebró el 27 de enero, en el cual Fausto Casarelli, Abogado Consistorial y canónigo de San Pedro, hizo la oratio o alegato en favor de la canonización del beato Isidro y Nicolás Zambecaro, también Abogado Consistorial y Secretario de la Congregación de Obispos, para los beatos Ignacio y Javier. El 1 de febrero se celebró el consistorio público para los dos restantes candidatos, estando a cargo de Juan Bautista Milino, Abogado Consistorial, la oratio por la beata Teresa y de Juan Bautista Espada, coadjutor del Abogado Espada, su tío, por el beato Felipe. A todos ellos respondió en nombre del Papa su secretario Juan Ciampoli y el propio Gregorio XV exhortó a orar y hacer penitencia para que Dios se dignara manifestar lo que fuera para mayor gloria suya y provecho de la Iglesia ${ }^{63}$. Por último, los consistorios semipúblicos, tuvieron lugar el 15 de febrero para los tres primeros y el día 28 para los otros dos beatos. Participaron 32 cardenales y otros tantos obispos y arzobispos, quienes dieron su voto por escrito para cada uno de los beatos, realizando grandes elogios de todos ellos. Conformes, por tanto, en la pertinencia de la canonización, animaron al Papa a celebrarla, el cual confirmó oficialmente que tendría lugar el siguiente 12 de marzo ${ }^{64}$.

Desde el punto de vista económico, la canonización colectiva -a priori- resultaba más ventajosa para los promotores. Con todo, los gastos fueron enormes ${ }^{65}$, calculándose que solo los jesuitas aportaron para las celebraciones algo más de veinte mil escudos ${ }^{66}$, sin contar el importe de la construcción del teatro, que sufragaron íntegramente los promotores de la causa de san Isidro ${ }^{67}$.

Gregorio XV pensó que las cantidades que deberían aportar cada uno podrían destinarse a las necesidades derivadas de la lucha contra los protestantes en Alemania; para ello encargó a dos cardenales sondear las diversas sensibilidades: los generales de los jesuitas y de los carmelitas descalzos se mostraron dispuestos a contribuir para los gastos de la Liga católica, y el embajador del Emperador, Federico Savelli, logró convencer a sus homólogos de España y Toscana en la misma dirección ${ }^{68}$.

62 AAV, Acta Camerarii, 15 (1615-1624), ff. 187-188v; BV, Bar. Lat. 2817, ff. 488v-489.

63 AAV, Arm XLV, 22, ff. 322v-328v; BV, Bar. Lat. 2817, ff. 489-493.

64 BAV, Bar. Lat. 2817, ff. 496v-497, 500-501.

65 ACOR, A IV 13, ff. 650-653 y ss. para la causa de San Felipe Neri. PAPA, Le cause di canonizzazione, pp. 287-290.

66 Ilario M. AZZOLINI, Quanto fu speso per la solennità della Canonizzazione dei ss. Ignazio e Francesco?, en La canonizzazione dei santi, pp. 127-129. El prepósito de la Compañía dice que solo en cera se gastaron más de mil ducados.

67 Alessandra ANSELMI, Roma celebra la monarchia spagnola: il teatro per la canonizazione di Isidoro Agricola, Ignazio di Loyola, Francesco Saverio, Teresa di Gesù e Filippo Neri (1622), en José Luis CoLOMER (ed.), Arte y diplomacia de la Monarquía Hispánica en el siglo XVIII, Madrid, 2003, pp. 231241.

68 GIORdano, Domenico di Gesù Maria Ruzola (1559-1630), p. 210. 
Los días previos a la canonización, en todas las iglesias donde debían celebrarse los homenajes posteriores a los nuevos santos, la actividad era febril, singularmente en el Gesù, donde el 28 de febrero en solemne procesión se trasladó el cuerpo del beato Ignacio a su nuevo altar ${ }^{69}$.

\section{LA SOLEMNE CEREMONIA}

La ceremonia de canonización constituyó un hecho sin precedentes. La solemnidad de la ceremonia se unió a toda una serie de celebraciones populares que no solo tuvieron lugar en Roma sino que, desbordándose desde el centro del mundo católico a las diversas periferias, llenaron de júbilo pueblos y ciudades $\mathrm{y}$, de manera muy particular, a los devotos de los nuevos santos. Por las repercusiones que tuvo, considera Leone que constituyó lo que hoy se denomina un evento mediático de acuerdo con la teoría de la comunicación ${ }^{70}$.

Desde la canonización de san Diego de Alcalá se había introducido la costumbre de levantar un elegante edificio de arquitectura efímera, en forma de gran teatro o platea, en torno a la sede petrina que abarcaba todo el ábside y la zona central del crucero, incluyendo el altar mayor, de la basílica Vaticana. Tenía una doble utilidad; por una parte contribuía a realzar el acto (todavía no existía ni el altar de la Cátedra ni el gran baldaquino de Bernini) mientras que, por otra, servía también para acomodar a los muchos asistentes invitados. Dicho teatro constituía propiamente una especie de sancta sanctorum dentro del gran templo, una arquitectura efímera que transfiguraba el espacio central de la basílica de San Pedro y le confería una apariencia única conforme al carácter absolutamente irrepetible de la ceremonia a la que servía de escenario. En verdad, se trataba de un theatrum sacrum, el más idóneo de los espacios para una liturgia fastuosa y barroca como era la que se desarrollaba durante la ceremonia de elevar a los siervos de Dios a la gloria de los altares.

Como ya se ha indicado, el comisionado Diego de Barrionuevo, encargó el diseño y la dirección de la obra al pintor Paolo Guidotti Borghese. A partir del documentado estudio de Alessandra Anselmi se conocen todos los detalles referentes a esta

69 Copia de unas cartas de los Padres de la Compañia de Iesus fechas en Roma a 21 de março, escritas a los Padres de Castilla, en que se da cuêta de lo sucedido en las canonizaciones de los cinco santos Isidro, Ignacio, Francisco, Teresa, y Filipo, hechas por nuestro muy S.P. Gregorio XV a doze de março de 1622, con dos insignes milagros que sucedieron en el mismo tiempo de su canonizacion, a intercession de los dos gloriosos santos san Ignacio, y san Francisco Xauier, Ympresso en Seuilla por Matias Clauijo..., 1622 (p. 1).

70 Massimo LeONE, Saints and Signs. A Semiotic Reading of Conversion in Early Modern Catholicism, De Gruyter, Berlin-New York, 2010, p. 9. 
magna arquitectura efímera ${ }^{71}$. Una completa descripción quedó consignada en la obra de Giovanni Briccio, publicada poco después de la canonización ${ }^{72}$. Además, todavía es posible ver la disposición del teatro gracias al grabado conmemorativo, abierto por el afamado grabador Matheo Greuter y estampado en Roma en aquel mismo año ${ }^{73}$. Está dividido verticalmente en tres calles, siendo la central un poco más ancha y en la que se incluye la vista del teatro levantado para la ceremonia; bajo ella se encuentra una gran cartela con el texto informativo. En las calles laterales aparecen, en la de la izquierda, san Isidro en la parte superior y santa Teresa en la inferior; y en la derecha, arriba los santos Ignacio y Francisco Javier, y debajo, san Felipe Neri; rodeándolos ocho escenas con los milagros obrados. Las imágenes de los santos corresponden a las que aparecieron en los estandartes confeccionados para la canonización.

A todos cuantos contemplaron aquel magnífico teatro les sorprendió que la decoración estuviera exclusivamente referida al beato Isidro. Briccio, en su descripción, aportaba el motivo:

Había decidido ya el papa Paulo V canonizar a san Isidro; y, habiendo fallecido, el papa Gregorio, que le sucedió, ordenó que se levantara el aparato [efímero] para celebrar la mencionada canonización. Pero, mientras en la basílica Vaticana se estaba construyendo un bellísimo teatro de madera a dicho efecto, siendo urgido por diversos príncipes, tomó la resolución de canonizar también a los otros cuatro. Pero los españoles, que estaban haciendo fabricar el mencionado teatro para san Isidro, no quisieron que en él se pusiera ningún ornamento ni pintura relativa a los otros santos, sino solo para san Isidro ${ }^{74}$.

Según se ha indicado, es posible afirmar que este predominio iconográfico de san Isidro y de las armas del rey de España en la basílica de San Pedro respondieron,

71 ANSELMI, Roma celebra la monarchia spagnola, pp. 223-230. En las pp. 231-241 incluye los «capitolati con gli artigiani per la realizzazione del teatro», con todos los datos referentes a los diferentes artistas y artesanos que participaron en su construcción y decoración. Se trata, por tanto, de un texto de referencia ineludible. También Maurizio FAGIOLO DELL'ARCO y Silvia CARANDINI, L'effimero barocco. Strutture della festa nella Roma dell'600, Bulzoni, Roma, 1977, pp. 54-56.

72 Giovanni BRICCIO, Relatione sommaria del solenne apparato, e ceremonia fatta nella Basilica di S. Pietro di Roma, per la canonizatione de gloriosi Santi Isidoro di Madrid, Ignatio de Lojola, Francesco Xauerio, Teresa Di Giesu, e Filippo Nerio Fiorentino, canonizati dalla Santità di N. S. Papa Gregorio XV à dì 12 di marzo MDCXXII, Per Andrea Fei, Roma, 1622.

73 Sus dimensiones son $51,7 \mathrm{x}, 36,3 \mathrm{~cm}$.

74 BRICCIO, Relatione sommaria dell solemne apparato, s.p. De forma parecida se expresa Giacinto GIGLI, Diario Romano (1608-1670), a cura di Giuseppe Ricciotti, Tumminelli Editore, Roma, 1958, p. 57 58: «Ma prima che io entri a descrivere il tenor delle cartelle, è da sapere che il theatro fu fatto solamente per la canonizzazione di S. Isidoro, il quale essendo quasi compito, piacque al Sommo Pontefice di canonizare insieme con lui altri quattro Santi, de' quali fu fatto instanza grande; e per questo le historie e cartelle di detto theatro non sono salvo che appartenenti a S. Isidoro». 


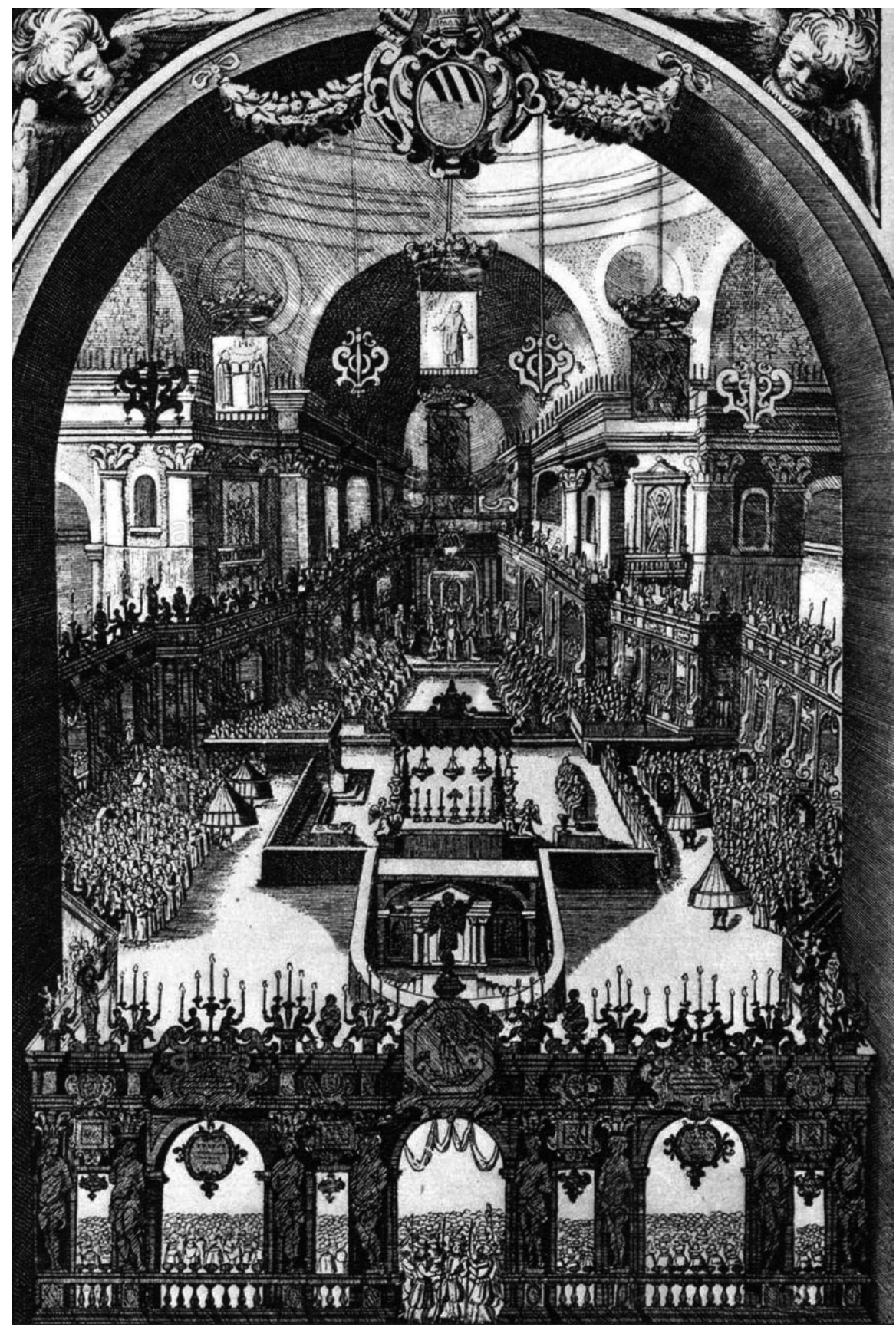

Detalle del grabado conmemorativo de la canonización, Matheo Greuter, Roma 1622.. 
en el fondo, a un equilibrio diplomático por el que Gregorio XV permitió dicho despliegue emblemático hispano a cambio de que el monarca transigiera con la canonización del resto de nuevos santos, incluidos los promovidos por la Corte de París. De este modo, el Papa no se indisponía ni con el rey de España ni con el de Francia pues a ambos contentaba de algún modo, haciendo gala de la afamada diplomacia vaticana.

Como fuente principal para el relato de la ceremonia, utilizo una relación manuscrita en lengua latina que, con toda probabilidad, redactó el protonotario apostólico monseñor Stephanus Salvius para dar fe del acto. La misma que luego tradujo al italiano, y publicó, Giovanni Briccio. Éste añadió datos referidos sobre todo a la decoración y a los aspectos más populares. Comienza ubicando con precisión el emplazamiento donde se levantó el teatro y sus dimensiones:

El lugar preparado para la celebración de esta solemne festividad fue la propia basílica de San Pedro del Vaticano, templo que por su grandiosidad, belleza y arquitectura supera a todas las demás basílicas del mundo; en ella, bajo la cúpula y en torno al altar mayor de los gloriosos Apóstoles fue construido el teatro, iniciándose su montaje muchos meses antes debido a sus grandes dimensiones: más de cien pasos de largo, sesenta de anchura y cincuenta palmos de altura. Los palcos, cuyos soportes quedaban en la parte trasera, ocupaban quince pasos del pavimento; y en cada uno de sus lados se había levantado una decoración, hecha toda de madera, a modo de arcos; entre cada uno de los arcos quedaba un espacio entre los cuatro ángulos en el que se construyeron posteriormente los asientos o graderío escalonado con muchas filas, de tal modo que los que estaban sentados en un lugar inferior no impidieran ver a los que estaban en otro más elevado. A estos graderíos se accedía por diversas puertas y escaleras, que estaban situadas en la parte posterior y que sólo permitían acceder a cada uno al sitio que tenía destinado.

«La platea de este teatro constaba de tres fachadas. La principal daba a las puertas de entrada del templo, hacia el oriente. Y las otras dos, en los laterales, estaban una enfrente de otra». En el centro de la principal, sobre la puerta, se colocó un gran cuadro de san Isidro haciendo manar agua de la roca con su bastón, bajo el cual se leía en una cartela: «Divo Isidoro Matritum D. D. cui se Patrono iam ante dedicavit» (Madrid a san Isidro, al que ya tenía como Patrón). A la izquierda el escudo de Gregorio XV con la leyenda: «Sic tua te praeside foelix vivat Hispania, Religionis propugnatrix, caelitum ferax» (Viva feliz España bajo tu pontificado, defensora de la Religión, fértil para el cielo). A la derecha, el de Felipe IV y en un letrero: «Sic Philippum serves incolumem diu et regiae in te pietatis aeques Imperium» (Que te conserves incólume, Felipe, por largo tiempo e iguale en ti el acierto en el gobierno a tu regia piedad). Por último, en el fondo, sobre el solio 
pontificio se había colocado un lienzo con la representación de san Isidro curando al difunto rey Felipe III de una enfermedad, motivo por el cual se había implicado tanto en su canonización ${ }^{75}$.

Flanqueaban cada puerta de la fachada principal dos grandes estatuas, que imitaban el color del bronce, sumando un total de ocho, que representaban los vicios puestos en fuga por las virtudes del santo dispuestas sobre los arcos a lo largo de todo el perímetro del teatro. Entre dichas figuras, por toda la cornisa del teatro aparecían los escudos del Papa, del rey de España, del embajador y de don Diego de Barrionuevo. Entremedio había una multitud de candelabros con velas encendidas. Además, por todo el teatro se habían repartido 41 cuadros con escenas de la vida de san Isidro y los milagros realizados, con cartelas donde aparecían relatados escuetamente y otras con los versos de una oda compuesta en su honor en lengua latina.

Colgaban en medio grandes candelabros plateados con infinidad de luces y cuatro enormes coronas (de más de 18 pasos de diámetro), situadas una al fondo del teatro, sobre la cátedra papal, dos hacia la mitad del recinto, una a cada lado, y otra en el centro; de las que pendían cuatro grandes estandartes con las imágenes de san Isidro (centro al fondo), san Ignacio y san Francisco Javier (izquierda), santa Teresa (derecha) y san Felipe Neri (en el centro cerca ya de la salida del teatro). Esta era la escueta representación icónica reservada al resto de canonizandos.

Refulgía la basílica llena de luz mientras sonaban los instrumentos musicales aguardando el inicio de la solemne ceremonia. Todos sus altares estaban profusamente adornados y con gran número de cirios, especialmente aquellos en los que se veneraban el «Sacrosanctum Christi Vultum nec non Sanctæ Lancex (...) et Sanctorum Reliquias». Destacaba obviamente el altar mayor, que se había cubierto con un baldaquino de madera de más de cincuenta palmos de altura, con cuatro columnas «alla antiqua», talladas y doradas, del que colgaban por sus cuatro lados caídas confeccionadas con ricas telas de brocado de oro y plata ${ }^{76}$.

El ambiente que reinaba en los aledaños de la basílica de San Pedro en la mañana del 12 de marzo de 1622 era realmente de gran fiesta. La plaza estaba decorada con festones, escudos y símbolos alusivos a san Isidro. Desde primera hora, empezaron a llegar carruajes que traían a los invitados. Entre los asistentes a la celebración cabe mencionar, por distintos motivos, por un lado a san José de Calasanz y, por otro, al conde de Monterrey que acudió como embajador extraordinario, enviado

75 Melchior RAMIREZ DE LEÓN, Relatione sommaria della vita, santità, miracoli et atti della canonizatione di S. Isidoro Agricola, patrone, e protettore della villa di Madrid..., Roma, A. Zannetti, 1622, p. 63.

76 Probablemente sirvió de inspiración para el que luego construyó Bernini en bronce; de hecho, a este célebre artista se le encargó el diseño del teatro para la canonización de santa Isabel de Portugal en 1625. 
por Felipe IV para rendir obediencia al nuevo papa Gregorio XV ${ }^{77}$. También se hallaban presentes el embajador ordinario, Francisco Fernández de la Cueva, duque de Alburquerque, así como los del emperador de Austria, del rey de Francia, del gran duque de Toscana, del dux de Venecia y de las demás repúblicas y principados italianos. Junto al solio pontificio se encontraban el excelentísimo señor duque de Fiano, hermano del Papa, el conde Nicolás Ludovisi, sobrino del Papa, y el príncipe Aldobrandini. La seguridad corría a cargo de la Guardia Suiza y de caballeros armados.

El continuo repicar de las campanas invitaba al júbilo en aquella fría mañana de marzo, en la que Roma rezumaba de alegría por la glorificación de cinco nuevos astros de la Cristiandad. Como refería Briccio:

Cada quien puede considerar qué magnífica, soberbia y fastuosa vista ofrecía toda la nave de la iglesia de San Pedro, toda adornada con los reposteros papales de seda y oro, hasta la cima de la cornisa y con tanta tapicería tejida en seda y oro, con historias del Nuevo Testamento, y ver después el teatro, con sus piezas doradas, plateadas y pintadas de colores, lleno de innumerables luces encendidas (...) donde en el supremo lugar se veía al Sumo Pontífice en su sede bajo un precioso dosel, y allí cerca a los embajadores de los reyes y duques, todos los ilustrísimos señores cardenales vestidos con riquísimos ornamentos sacerdotales y mitras de damasco blanco en la cabeza, y luego los patriarcas, arzobispos y obispos de la corte romana; de igual modo, la multitud de canónigos y clero presente, con el coro de la música. Pero el ver la gran muchedumbre del pueblo, que se sentaba sobre las escalinatas, del uno y otro sexo, con tanta diversidad de indumentaria, junto con la que se arremolinaba en la platea del teatro y la que inundaba la nave del templo, y la que caminaba por la calle del Puente de Sant'Angelo resultaba una verdadera maravilla.

La liturgia correspondiente a la canonización tuvo que desarrollarse en este ambiente pleno de júbilo pero también sometido a los inconvenientes del grandísimo concurso de fieles que abarrotaban por completo hasta el último rincón de la espaciosa basílica. En esta época, la ceremonia de la canonización estaba ya perfectamente configurada hasta en sus más mínimos detalles, según refiere Lambertini ${ }^{78}$. Han quedado algunas relaciones de la celebración, y un sucinto esquema de la misma publicado junto con una breve biografía de los cinco santos canonizados ${ }^{79}$. Una de

77 BNE, VC/1014/84: Relación de la embajada del conde de Monterrey a Roma cuando fue representado a Felipe IV a la canonización de santa Teresa de fesus y otros santos. 1622

78 Benedictus XIV, De servorum Dei beatificatione, I/1, pp. 725-767.

79 Breve relacion de las ceremonias hechas en la Canonizacion de los Santos Isidoro Labrador, Ignacio de Loyola, Francisco Xauier, Teresa de Iesus y Filipe Neri, Canonizados por la Santidad de nuestro muy Santo Padre Gregorio Papa XV, en 12 dias del mes de Março, año de 1622. En Madrid por Luis Sánchez. 
las relaciones más interesantes, por el destacado papel que desempeñó su redactor como maestro de ceremonias, es la de Paolo Alaelonis, que vamos a utilizar como fuente principal para la narración ${ }^{80}$.

Comenzó el ceremonial en torno a las 14 horas según el cómputo romano, es decir, hacia las nueve y media de la mañana ${ }^{81}$, en la capilla Sixtina, donde el Papa se revistió de los ornamentos sagrados (falda, amito, alba, cíngulo, estola y capa pluvial blanca con rico recamado, y mitra preciosa).

En primer lugar, puso incienso en el incensario, acercándole la naveta el prior Piestor Carliu; a continuación, el cardenal Ludovisi, sobrino del Papa, procurador de la canonización de los cinco beatos, después de haberlos besado, de acuerdo con la costumbre, entregó al Papa dos grandes cirios, que estuvieron ardiendo hasta la conclusión de la ceremonia, cuando se dieron, como manifestación de aprecio, a los señores oradores [embajadores] del Emperador y de Venecia.

Ante el altar de la capilla Sixtina se había colocado un faldistorio; allí y sin mitra, el Pontífice incoó el himno Ave Maris Stella, y se puso de rodillas, y habiendo cantado los cantores los primeros versículos, se levantó y tomó la mitra, dando comienzo la procesión, que encabezaba la Cruz, portada por el subdiácono apostólico. A continuación se situaron los miembros de la Curia, prelados, auditores, obispos y arzobispos, y cardenales, todos ellos con traje coral y capa pluvial blanca, así como los cantores. Finalmente, iba el Pontífice en la silla gestatoria y bajo palio, sosteniendo una vela encendida en su mano izquierda. Según refiere Alaelonis, el cortejo «bajó por la escaleras ordinarias a la basílica de San Pedro y no por la plaza debido al frío».

En el atrio se unieron a la procesión las representaciones de las órdenes religiosas y del clero romano así como los promotores de las cinco causas, llevando estos un estandarte de sus correspondientes santos. Desde el atrio, la procesión continuó por la vía sacra ingresando por su puerta principal en el teatro preparado para la ca-

80 BAV, Bar. Lat. 2817: «Pauli Alaleonis Diarium a die 30 octobris ad diem 2 maii 1622», ff. 503v507 (original en latín, traducción propia). A dicha relación pertenecen todos los párrafos entrecomillados en este epígrafe sin referencia específica. Habitualmente, para descargar el texto, he suprimido los títulos honoríficos como, por ejemplo, «el Ilustrísimo Señor Cardenal». De este texto se valió también el P. Antonio de SAN JOAQUíN, Año Teresiano: diario historico, panegyrico moral, en que se descriven las virtudes, sucessos, y maravillas de... Sta. Teresa de Jesus, assignadas a todos los dias de los meses en que sucedieron..., t. III, En la Imprenta y Librería de Manuel Fernández, Madrid 1738, pp. 219-227 para su «Relación de las ceremonias y singularidades con que se celebró la canonización de Nuestra Madre Santa Teresa de Jesús».

81 El cómputo de las horas en Roma comenzaba a partir del toque del Ángelus de la tarde que, teóricamente, se daba media hora después de ponerse el sol, variando por tanto a lo largo del año: en marzo, a las siete y media de la tarde. 
nonización, desde allí cada cual marchó a colocarse donde le correspondía y el Papa continuó hasta el ábside para ocupar su trono. Este itinerario «desde la residencia del sucesor de Pedro al lugar del martirio del Apóstol es un discurso que apoya sobre Pedro el poder y la primacía de su sucesor, a la vez que lo exalta. Lo que se revela también a partir de la escenografía $\gg^{82}$.

Una vez que el Papa se hubo sentado en la sede, recibió la acostumbrada obediencia de los patriarcas, arzobispos y obispos asistentes, que le besaron la mano. Por su parte, los obispos no asistentes [al solio pontificio] pasaron a besarle la rodilla, y los penitenciarios de San Pedro a besarle el pie. Acabado lo cual, se presentó delante del Papa el cardenal Ludovisi, procurador de todos los beatos que se iban a canonizar ${ }^{83}$, y estando ante el más bajo de los peldaños del solio, en medio del Señor de Labeccariis, abogado consistorial, y del Ceremoniero mayor, puestos de rodillas, el Abogado hizo la primera petición [de que canonizara a los cinco beatos] al Papa, como es costumbre, en nombre de la Sacra y Cesárea Majestad, de los reyes y príncipes católicos. Y hecha esta primera petición, en nombre del Papa respondió don Juan Ciampolus, su secretario, con un elegante discurso. Y el Papa descendió al faldistorio y se arrodilló, con mitra, junto con todos los demás mitrados, y fueron cantadas las letanías ordinarias, como en el breviario hasta el Agnus Dei y el Kirie.

Cantadas las letanías, el Papa volvió a la sede y se sentó, y fue hecha la segunda petición, urgiéndola, como la primera vez el Abogado consistorial, al que respondió brevemente el mismo secretario. El Papa descendió desde el solio y se puso de rodillas en el faldistorio. El cardenal diácono asistente dijo en alta voz: «Oremus», el Papa se quitó la mitra y todos oraron durante un corto espacio de tiempo hasta que el cardenal diácono asistente que estaba a su izquierda dijo en voz alta: «Levate». Todos se pusieron de pie y el Papa, estando sin mitra junto al faldistorio, incoó el himno Veni Creator Spiritus mientras los obispos asistentes, que fueron el Patriarca de Jerusalén y el Arzobispo de Bari, y los demás sostenían una vela en sus manos. Puesto de rodillas a los primeros versos, se levantó, tomó la mitra y volvió al solio, y en la sede se quitó la mitra, y sin ésta, permaneció mientras los cantores cantaban el himno Veni Creator Spiritus. Acabado el cual,

82 TURCHINI, La fabbrica di un Santo, p. 10: «dalla sede residenziale del succesore di Pietro al luogo del martirio dell'Apostolo, è un discorso que poggia su Pietro e che esalta il suo succesore, il suo potere, il suo primato. Ció viene rivelato anche dalla scenografia».

83 Se evitaba así entrar en el peligroso juego de las precedencias entre naciones, como pone de manifiesto una anotación recogida por Pietro TACCHI VENTURI, La canonizzazione e la processione dei cinque Santi negli scritti e nei disegni di due contemporanei (Giovanni Bricci, Paolo Guidotti Borghese), en La canonizzazione dei santi, p. 58: en un libro manuscrito Consultata (1611-1626), que contiene las consultas realizadas por el General de la Compañía con sus asistentes, de fecha 10/2/1622, refiere haber concertado con el ceremoniero Alaleoni que fuera el cardenal Ludovisi el procurador «quia ipse est de quo nulla natio potest conqueri, nulluus princeps queri». 
dos cantores entonaron el versículo «Emitte Spiritum tuum», al que respondieron los cantores, y el Papa, tomándola del libro, cantó la oración siendo ayudado por el cardenal del Monte, obispo de Porto, que vino al solio y se sentó junto al faldistorio según costumbre.

Cantada la oración, se acercó por tercera vez el cardenal Ludosivi con el Abogado y el Maestro de Ceremonias, y el Abogado hizo la tercera petición, urgiendo todo lo posible la canonización, y el Secretario respondió brevísimamente ${ }^{84} \mathrm{y}$, estando sentado el Papa, leyó del libro la sentencia que, pronunciada por el Abogado, pedía en nombre del Procurador, el cardenal Carlos Ludovisi, que decretara las bulas [de canonización]. Y el Papa dijo: «Decretramus».

El decreto de la canonización, traducido del latín, dice:

«A honra de la santa y una Trinidad y exaltación de la fe católica, y aumento de la Religión cristiana, con la autoridad del mismo Dios Todopoderoso, Padre, Hijo y Espíritu Santo, y de los Santos apóstoles Pedro y Pablo, y nuestra, habiendo tomado consejo de nuestros hermanos, determinamos y definimos que los sujetos de buena memoria Isidro Labrador, patrón de Madrid; Ignacio de Loyola, del lugar de Azpeitia, fundador de la Compañía de Jesús; Francisco Javier, de la misma Compañía de Jesús; Teresa de Jesús y Ahumada, abulense, fundadora de la Orden de Carmelitas Descalzos; y Felipe Neri, florentino, fundador de la Congregación del Oratorio, son Santos y dignos de ser inscritos en el catálogo de los Santos; y como a tales los inscribimos en dicho catálogo, determinando que todos los años, el día del óbito de Isidro, Ignacio, Francisco y Felipe, se celebre su fiesta devota y solemnemente con oficio de confesor no pontífice, y en el de Teresa, con el oficio para una virgen. Más aun, valiéndonos de la misma autoridad, a todos los que verdaderamente arrepentidos y, habiéndose confesado, visitaren devotamente sus sepulcros, cualquier año en los días de sus festividades, concedemos un año y cuarenta días de indulgencia, y a los que lo hicieren en las Octavas de sus fiestas, concedemos cuarenta días ${ }^{85}$.

84 El texto de la respuesta es el siguiente: «Audite, caeli, quae loquor; audiat terra verba oris mei (Deut., XXXII, 1) «Cum e re christiani nominis esse sibi pie persuadeat Sanctissimus Dominus Noster, caelestes honores quinque hisce Beatis decerni, divino numine instinctus ex altissima hac christianae sapientiae cathedra, quam divinae veritatis oraculum Deus ipse constituit in terris, Isidorum Agricolam, Ignatium Loyolam, Franciscum Xaverium hispanos, Philippum Nerium florentinum in Sanctorum Confessorum catalogum, Theresiam de lesu hispanam in Sanctarum Virginum numerum referendos esse pronunciat».

85 BAV, Bar. Lat. 2817, ff. 506-507: «Ad honorem Ste et Individuae Trinitatis, et exaltationem fidei Catholicae ac Christianae Religionis, augmentum authoriate eiusde Dei omnipotentis Patris, et Filii et Spiritus Sancti, Beator. Apostolor. Petri et Pauli et nostra, de fratrum nostror. Consilio Decernius et Diffinimus bone Memoriae Isidori Agricolae, Patronum Matriti, Ignatium Laiola oppidi Azpeythiae, Societatis Jesú fundatorem, Franciscum Xavier eiusdem Societatis Jesú, Theresiam a Jesú de Ahumada, Abulense, Ordinis Carmelitar. Discalzator. Fundatricem, et 
El cardenal Ludovisi subió al solio y, arrodillado, besó las manos del Papa y le dio las gracias. Por su parte, el Abogado rogó a los protonotarios, secretarios y notarios presentes que redactaran instrumentos que dieran fe del acto ${ }^{86}$.

Inmediatamente, comenzaron a sonar las trompetas de plata, y en la plaza de San Pedro y en el castillo de Sant'Angelo se dispararon bombardas. Se levantó el Papa y entonó el himno Te Deum, a cuya finalización el cardenal Bonconpagni, que actuaba como diácono asistente a la derecha del Papa, cantó la oración compuesta para los cinco nuevos santos:

«Oh, Dios que has querido ser glorificado en la gloria de tus santos y nos permites honrarte honrándolos a ellos, concédenos propicio que sintamos en nuestras almas el piadoso patrocinio de tus beatos Isidro, Ignacio, Francisco, Teresa y Felipe, cuyos gloriosos méritos veneramos. Por Jesucristo, nuestro Señor. Amén ${ }^{87}$.

Seguidamente, el Papa volvió al solio. El cardenal d'Este, que actuaba de diácono, cantó el Confiteor nombrando, después de los apóstoles, a los nuevos santos. Luego, regresó a su lugar, entre los otros señores cardenales, y el Papa cantó las preces, nombrando a todos los beatos canonizados. Después de sentarse, y recibir la mitra, fueron apagadas las velas del Papa y de los embajadores.

Tras cantar la hora Tercia, el Papa «cantó la Misa de la fiesta de San Gregorio con la segunda oración de los santos canonizados». Al concluir el ofertorio tuvo lugar uno de los ritos más vistosos de la ceremonia, la ofrenda por parte de los pro-

Philippum Nerium, florentinum, Congregationis Oratorii fundatorum, Sanctos esse ac sanctor. Cathalogo adscribendos ipsosq. Cathalogo huismodi adscribimus statuentes, ut ab Universali Eccl(essi)a anno quolibet in die obitus Isidori, Ignatii, Francisci, et Philippi festum ipsor. et officium sicut pro uno confessore no Pontifice, Teresiae vero sicut pro una Virgine tm deote ac solemniti celebren. Insuper eadem Auctoritate omnibus vere penitentibus, et confessus, qui annis singulis eisdem diebus festis ad sepultura eorumdem devote acceserinnt unum annum et $40^{\mathrm{a}}$ dies, accedentibus vere annis singulis in octavas dictor. festor. ad sepultura quadraginta de invinctis penitentiis misericordr (sic) relaxamus».

86 En la iglesia del Gesù de Roma, sobre la puerta de la sacristía, existe un lienzo de autor desconocido que representa este momento de la ceremonia, en el cual el cardenal Ludovisi se encuentra ante el Papa, que decreta la inclusión de los cinco beatos en el catálogo de los santos. En segundo plano aparece el general de la Compañía con el estandarte de los santos Ignacio y Francisco Javier. Al pie se indica: «Gregorii XV P. M. et Card. Ludovisii inmortalitatibus meritis». Un cuadro similar hay también en el convento de MM. Carmelitas de Alba de Tormes, en el que se ha sustituido el estandarte de los santos jesuitas por el de santa Teresa, que portan unos carmelitas descalzos.

87 «Oratio: Deus qui glorificantes, te glorificas, et in Sanctor(um) tuor(um) honoribus honoraris, concede propitius ut qui Beator(um) tuor(um) Isidori, Ignatii, Francisci, Theresie atq Philippe gloriosa merita colimus, cor pia patrocinia sentiamus. Per Xpum Dnum nostrum». 
motores de las canonizaciones de dos cirios ${ }^{88}$, dos panes grandes de cera (uno dorado y otro plateado) y dos barriles de vino. Además se ofrendaban tres canastillas con aves vivas, por cada uno de los canonizados, la primera de ellas era de color dorado y contenía dos tórtolas, la segunda era plateada con dos palomas blancas en su interior, y la tercera, que estaba pintada de alegres colores, albergaba numerosos pajarillos de especies diversas ${ }^{89}$. Según Aleolis:

Dicho el ofertorio por el Papa en la Misa junto a la sede, se sentó con la mitra puesta, y recibió el gremial, y se hizo el ofertorio de los panes de cera, barriles y canastillas con tórtolas, palomas y otras aves por cada uno de los santos canonizados, que efectuaron los quince señores cardenales de la Sagrada Congregación de Ritos y Ceremonias ${ }^{90}$. A la izquierda en primer lugar venía el cardenal del Monte, obispo de Porto, prefecto de la Congregación, y el cardenal Ludovisi, procurador de la canonización, que ofreció al Papa todos los cirios y canastillas con tórtolas, palomas y otras aves, y las redes de las canastillas de las aves fueron retiradas por mí, y las aves salieron volando.

Cabe imaginar el júbilo de los asistentes al ver volar las aves por las amplias naves de la Basílica, en donde permanecían durante el resto de la ceremonia, alegrando con sus trinos la solemnidad del momento. La Misa continuó como de costumbre, utilizándose las oraciones que se habían compuesto para la ocasión que, además de la colecta arriba traducida del latín, eran las siguientes:

Secreta

«Que lleguen a ti, Señor, nuestras ofrendas por medio de tus santos Isidro, Ignacio, Francisco, Teresa y Felipe para que estos sagrados misterios, en los cuales pusiste la fuente de toda santidad, nos santifiquen en la verdad. Por Jesucristo, nuestro Señor» ${ }^{91}$.

88 Los cirios estaban finamente decorados y todos llevaba pintado el escudo de Gregorio XV. En el caso de los que se entregaron como ofrenda por la canonización de san Isidro llevaban también las armas del rey de España. Los que se ofrecieron por san Ignacio incluían, junto a las armas pontificias, el anagrama de la Compañía y el nombre del santo. Cfr. TACCHI VENTURI, La canonizzazione e la processione, p. 61.

89 Benedictus XIV, De servorum Dei beatificatione, I/1, pp. 751-761.

90 Hicieron las ofrendas: por san Isidro, los cardenales del Monte, Peretti y Madruzzo; por san Ignacio, Millinus, Leni y Crescentio; por san Francisco Javier, Muti, Savelli y Valerio; por santa Teresa, Zoleri, Gherardo y Scaglia; y por san Felipe Neri, los cardenales Pignattello, Sagrato e Gozzadino.

$91 \ll$ Secreta: Adsint, Dne Deus oblationibus n(ost)ris Sanctor. tuor. Isidori, Ignatii, Francisci, Theresie atq Philippe benigna suffragia ut sacro sancta misteria in quibus omnis Sanctitatis fonte constituisti Nosquoque in veritate sanctificent. Per Dnum Nrum.». 


\section{Postcomunión}

«Señor, que esta ofrenda de alabanza, que hemos ofrecido en acción de gracias por tus santos Isidro, Ignacio, Francisco, Teresa y Felipe, nos alcance por su intercesión cantar por siempre la alabanza de tu Majestad. Por nuestro Señor...» ${ }^{92}$.

Al fin de la Misa, el Papa concedió indulgencia plenaria, que hizo pública el cardenal del Monte.

Respecto a las bulas de la canonización, cabe señalar que, salvo la de santa Teresa, tardaron en publicarse oficialmente. Gregorio XV falleció el 8 de julio de 1623 sin rubricar las de san Ignacio, san Francisco Javier y san Felipe Neri, por lo que hubo de ser su sucesor Urbano VIII quien las firmara y mandara publicar con la significativa fecha del 6 de agosto de dicho año, día de su elección. Sin que se sepa a ciencia cierta el motivo, la bula de canonización de san Isidro fue publicada de nuevo en 1721 durante el pontificado de Benedicto XIII ${ }^{93}$.

\section{ROMA FESTEJA A LOS NUEVOS SANTOS}

Los festejos por la canonización fueron sonados, a pesar del tiempo cuaresmal y de la inminencia de la Semana Santa. El sábado 12 de marzo por la tarde el ambiente era de auténtica fiesta, especialmente en torno a las iglesias de los nuevos santos. Giacinto Gigli en su Diario refiere:

Después que se hubo celebrado la canonización con las ceremonias acostumbradas, de inmediato se produjeron grandísimas demostraciones de júbilo: sonaron las trompetas, los tambores, las campanas, se dispararon cohetes y salvas de artillería. Y se hicieron regocijos en la iglesia de Santiago de los españoles por la canonización de san Isidro, en el Gesù por la de san Ignacio y san Francisco Javier, en la de Santa María della Scala, en el Transtevere, por la de santa Teresa de

$92 \ll$ Postcomunio: Laudis hostia Domine, qua pro Sanctis tuis Isidoro, Ignatio, Francisco, Theresia atq Philippo gratias agentes obtulimus ad perpetuam nos Maiestatis tue (sic) laudatione eor. intercessione perducat. Per Dmum.».

93 La de san Isidro no aparece en el Magnum Bullarium; la publicó Benedicto XIII en 1721 (Bullarium Romanum, t. XI, pars altera, Roma 1736, pp. 279-281; la de santa Teresa en Mag. Bull., t. III, Luxemburgo 1742, pp. 465-469; la de san Felipe Neri en Mag. Bull., t. IV, Luxemburgo 1727, pp. 2-7; la de san Ignacio en Idem, pp. 7-12; y la de san Francisco Javier en Idem, pp. 12-19. En la edición de Turín: Bullarium Romanum, t. XII, Turín 1867, pp. 483-492 (san Isidro) y 673-682 (santa Teresa); XIII, Turín 1868, pp. 11-22 (san Felipe Neri), 23-33 (san Ignacio) y 33-45 (san Francisco Javier). Resulta sorprendente el descuido que hubo en la redacción y publicación de las bulas. 
Jesús, y en la de Santa María in Vallicella, también llamada Chiesa Nuova, por la de san Felipe Neri. Ese día se hicieron muchas limosnas en diversos lugares y por diversas personas, también de forma privada y particular. Así, los padres del Gesù repartieron entre los pobres una gran cantidad de panes blancos, de una libra la hogaza. $\mathrm{Al}$ atardecer se hicieron grandes luminarias por todas las calles y en casi todas las casas de Roma, quemando toneles y poniendo candelas en las ventanas, y particularmente los padres de la Compañía no solo llenaron de luces todas las ventanas y la cornisa del Colegio Romano, y quemaron toneles e hicieron la girándola (rueda de fuego) sino que, en la iglesia del Gesù, llenaron de luces toda la cúpula, que daba gusto verla, y toda la fachada desde la cornisa hacia abajo estaba llena de fuegos artificiales, que parecía una maravill $a^{94}$. Las fachadas de las otras tres iglesias correspondientes a los otros santos canonizados estuvieron también llenas de luces; y estos fuegos y regocijos con tambores y trompetas, campanas y cohetes se hicieron igualmente al atardecer de los dos días siguientes.

Por la canonización de san Isidro, la iglesia de Santiago de los españoles fue toda ella recubierta en su interior, de manera muy noble, con diversas tapicerías de seda, y adornada con mucha plata. Lo mismo se hizo por la de santa Teresa en la iglesia de Santa María della Scala. Pero la Chiesa Nuova fue tan ricamente adornada de soberbios tapices recamados, tan bien distribuidos, que junto con la grandísima cantidad de plata, no se vio otra iglesia que la superase en cuanto a la decoración ${ }^{95}$.

Por lo que se refiere a la iglesia del Gesù, habiendo llevado sus tapices para colgarlos en San Pedro, no le faltaron sin embargo las más bellas tapicerías y cortinas, que le prestaron cuatro cardenales, de modo que por lo que se refiere a la decoración, el diseño y la novedad de diversas cosas, hechas casi de improviso, no hubo iglesia que la pudiese igualar. La fachada de la iglesia fue adornada con cuatro estatuas de estuco puestas en cuatro hornacinas, a saber, una representaba a san Ignacio, otra a san Francisco Javier, y estas dos estaban en la parte inferior; encima estaban la Iglesia Romana y la Cristiandad del Japón.

Además se habían colgado, con un agradabilísimo diseño, muchos cuadros de pintura amarilla oscura hechos a posta, y diversos frisos de pintura y festones, e inscripciones, que eran cosa bellísima; porque no cubrían toda la fachada de la iglesia, sino que se habían acomodado entre las columnas y las pilastras de modo que, sin romper el diseño propio de la fachada, la hacían parecer distinta con esta

94 Corroborando lo dicho, en una carta dirigida a los jesuitas de España refería el prepósito de la Compañía, que hubo música, luminarias y fuegos artificiales, y se iluminó la cúpula del Gesù con «al pie de dos mil luminarias, que hazían una apacible vista» (BNE, Mss/18168). Presutti dice que se pusieron 900 luces en la cúpula y más de 200 en la linterna, que junto con las que se pusieron en la fachada de la iglesia y ventanas de la casa sumaban más de 2.000. También señala que se quemaron once castillos de fuegos artificales. También indica la iluminación preparada en el Colegio Romano (TACCHI VenTURI, Il fratel Antonio Presutti, p. 89).

95 Existe un cuadro $(98 \times 74$ cms.) conservado en la Pinacoteca de los Museos Vaticanos, pintado por Andrea Sacchi (1599-1661), en el que se ve el interior de dicha iglesia con la decoración dispuesta para la canonización. 
nueva perspectiva. Dentro de la iglesia se hizo una decoración en torno al altar de san Ignacio a todo lo largo de la fachada con cinco cuadros pintados en los cuales se representaba la vida del santo; en cuyo altar, que era de piedra, con dos preciosas columnas, se puso la imagen de san Ignacio; y dentro del altar fue colocado su cuerpo, el cual hasta entonces había estado sepultado a la mano derecha del altar mayor.

Enfrente de este altar fue fabricado en madera otro altar, en todo igual a éste, con columnas y pinturas, que asemejaban piedras finísimas y verdaderas, y en el que fue puesto el cuadro de san Francisco Javier, con su vida igualmente pintada en cinco cuadros, de acuerdo con la mencionada fachada que tenía enfrente. Por otra parte, dentro del friso de la cornisa, que rodea toda la iglesia, fueron acomodados 101 cuadros, en los cuales estaban pintados los retratos de otros tantos mártires de la misma Compañía, y entre un cuadro y otro aparecía un escudo de madera tallada, pintada y dorada con el nombre de JHS, de modo que dichos retratos y el nombre de Jesús recubrían el friso de la cornisa por todo el perímetro de la iglesia. Todos los muros, desde la bóveda hasta la cornisa estaban cubiertos de tapicería, y sobre la cornisa misma se habían colocado en todo el circuito en torno a la iglesia muchísimos ángeles blancos, de relieve, que tenían en sus manos candelabros con velas de cera blanca encendidas, y entre un ángel y otro había numerosos candelabros, también con velas, que daban una impresión magnífica. Y de la cornisa hasta el suelo, toda la iglesia estaba tapizada con diversos brocados de oro y bellísimos paños de seda; sobre los cuales estaban colocados veinticuatro grandes cuadros con los milagros de los dos santos, repartidos de forma que en el ala de san Ignacio a lo largo de toda la iglesia estaban distribuidos sus milagros con las correspondientes inscripciones debajo, puestos entre una capilla y otra; y en la otra ala, frente por frente, estaban los milagros de san Francisco Javier.

En el arquitrabe, sobre las columnas del altar mayor había tres cuadros con los retratos de santa Teresa y san Felipe, y en medio el de san Isidro. Lo que pudo verse también en las otras iglesias donde se hizo la fiesta de estos santos, o sea que, además del propio santo, por el cual se hacía la fiesta, estaban también los retratos de los otros cuatro santos entonces canonizados ${ }^{96}$.

El gran acontecimiento previsto para el domingo 13 de marzo fue una magna procesión en la que se llevaron los estandartes de los nuevos santos a sus respectivas iglesias. Se celebró al concluir las Vísperas el cabildo de San Pedro. Quedan varias descripciones, más o menos detalladas, de dicha procesión que, partiendo del corazón simbólico de la Cristiandad, esto es de la basílica de San Pedro, recorrió las principales vías de la ciudad de Roma por un itinerario diseñado para ampliar, si cabe, los ecos de la gran jornada antecedente. Los nuevos santos, elevados a la gloria de los mayores héroes de la Iglesia, recorrían ahora las calles de Roma rodeados del clamor popular, en un clima de verdadera apoteosis. 
Giacinto Gigli nos ha dejado también un relato cargado de sabor sobre la magna procesión, que se ofrece a continuación traducido del italiano.

A 13 de marzo de 1622, que fue el día siguiente [a la canonización], domingo, se llevaron en procesión los estandartes de los cinco santos canonizados de la basílica de San Pedro a sus iglesias, la cual procesión fue de este modo: Marchaban al frente los capuchinos y después los frailes llamados Fatebenefratellii" ${ }^{97}$ luego los de Santa María de las Gracias ${ }^{98}$, de San Onofre ${ }^{99}$, de la Trinidad de los Montes ${ }^{100}$, de San Cosme y San Damián ${ }^{101}$, de los Santos Apóstoles ${ }^{102}$, los frailes Zocolantes ${ }^{103}$, todos con sus cruces delante ${ }^{104}$.

Después de estos venían los padres de la Congregación del Oratorio de Santa María in Vallicella, y con ellos unos cuantos presbíteros florentinos, todos con preciosos roquetes y gruesas velas en la mano (las cuales también llevaban de modo similar todos los frailes de las religiones [órdenes] mencionadas más arriba). A continuación, seguía la música, y detrás el estandarte de san Felipe Neri ${ }^{105}$.

Venían después con su cruz los frailes de santa Teresa, que están en [el convento] de la Madonna della Scala, y con ellos venían entremezclados los frailes conventuales del Carmen y después la música con su estandarte de santa Teresa. Seguía después la cruz de los presbíteros del Colegio Germánico y otros colegios de los padres jesuitas, también con velas encendidas y con roquete, y después los padres de la Compañía de Jesús, todos con roquete, y con la música venía un estandarte, en el cual estaban las imágenes de san Ignacio y de san Francisco juntas.

97 Son los Hermanos de San Juan de Dios, a los que en Italia se les conoce así, por la forma en que iban pidiendo limosna por las calles para el hospital de San Bartolomé de la isla Tiberina: Fate bene, fratelli (Haced el bien, hermanos).

98 Se trataba de una congregación de eremitas que atendía el hospicio de santa Maria delle Grazie a Porta Angélica. Parece más difícil que se trate, como se ha afirmado, de los trinitarios de Santa Maria delle Grazie alle Fornaci porque no se hicieron cargo de dicha iglesia hasta 1721.

99 Eran los frailes de la Congregación de ermitaños pobres de San Jerónimo, fundada por Pietro Gambacorta y Nicola da Forca Palena hacia 1442.

100 Los mínimos de San Francisco de Paula.

${ }^{101}$ Los franciscanos del Tercer Orden Regular

102 Los franciscanos menores conventuales

103 Según la Enciclopedia Trecanni era la forma popular de referirse a los religiosos de la Orden de Frailes Menores, los franciscanos.

${ }^{104}$ Existe otra relación de las comunidades religiosas que participaron en la procesión: «Prima le fratarie con le sue croci coperte; e queste furono li Frati di San Giovanni Calibita, quelli della Redentione, di Sant'Adriano, quelli di Sant'Onofrio, li Minimi, quelli di San Francesco, cioè Capuccini, del Terzo Ordine et Zoccolanti, Conventuali; quelli del Carmine, cioè Reformati Scalzi, della Traspontina et della Congregatione de Mantua» (Pietro TACCHI VENTURI, La canonizzazione e la processione dei cinque Santi negli scritti e nei disegni di due contemporanei [Giovanni Bricci, Paolo Guidotti Borghese], p. 64). Se unirían, por tanto, a los ya mencionados, los trinitarios y los mercedarios. Y destacaría aún más la clamorosa ausencia de los dominicos y los agustinos.

105 Dicho estandarte se conserva hasta la actualidad en las estancias de san Felipe en la Chiesa Nuova. 
Finalmente, venía con la cruz una gran multitud de curas españoles con roquete y, como ya he dicho, todos con velas encendidas, y con otro coro de música, venía el estandarte de san Isidro: y con este orden salieron de San Pedro.

Desde la iglesia de Santa María in Vallicella salieron al encuentro de la procesión más de trescientos caballeros con antorchas encendidas en la mano, al llegar al puente de Adriano se incorporaron a la procesión delante del estandarte de san Felipe, y llegada que fue la procesión a la Chiesa Nuova se detuvo y el estandarte fue depositado en la iglesia ${ }^{106}$, y después los padres del Oratorio, una vez dejado el estandarte, retornaron a la procesión situándose delante del estandarte de santa Teresa.

Al llegar a la estatua de Pasquino, torció la procesión hacia la Plaza di Agone [Navonna], donde fue depositado el estandarte de san Isidro en la iglesia de Santiago de los españoles, y a continuación estos se situaron en la procesión delante del estandarte de los santos Ignacio y Francisco. Y siempre que se dejaba un estandarte en su correspondiente iglesia, era recibido dentro de ella con música, $\mathrm{y}$ en el exterior con toques de trompetas y tambores.

De la Plaza de Agone marcharon a la Plaza Madama, y de allí a la Aduana a través de la Minerva y por [la calle] Cesarini entraron en la calle que va directa al Gesù, de donde salieron a recibir el estandarte un grandísimo número de caballeros y prelados de la congregación de la Asunción erigida en la Casa de los jesui$\operatorname{tas}^{107}$, con antorchas encendidas, y con ellos los Conservadores ${ }^{108}$ y el Senador de Roma ${ }^{109}$, los cuales se colocaron delante del estandarte, y al mismo tiempo venía por otra calle al encuentro de la procesión el Seminario Romano, que se colocó detrás del estandarte, igualmente con roquete y velas encendidas.

Dejado que fue el estandarte en el Gesư ${ }^{110}$, los padres de la Compañía y también todos los otros pasaron delante y se situaron en la procesión delante del estandarte de santa Teresa y, torciendo en la calle de las Botteghe Oscure, atravesaron el Puente Sixto hacia el Trastevere, a Santa María de la Scala, donde fue depositado finalmente el estandarte de santa Teresa ${ }^{111}$.

${ }^{106}$ BAV, Urb. Lat. 1091, f. 204. Bartolomeo Dardano indica que el estandarte de san Felipe fue recibido con gran solemnidad por monseñor Sansidonio, al que acompañaban los cardenales Crescentio y Gherardi.

${ }_{107}$ Presutti indica que fueron 150 prelados y señores de la Congregación con antorchas encendidas (TACCHI VENTURI, Il fratel Antonio Presutti, p. 90).

${ }^{108}$ Eran Marco Antonio della Porta (de Castello), Paolo Millini (de Parione) y Ferrante Verospi (de Colonna). Se denomina Conservadores de Roma (en italiano, Conservatori di Roma) a los tres magistrados que, como recuerdo de los antiguos senadores, y junto con el Priore dei Caporioni conformaban la Magistratura de Roma desde el siglo XIII hasta el año 1870. Eran elegidos por sorteo y su mandato duraba un trimestre. En este caso, del 1 de enero al 31 de marzo de 1622 .

109 En 1622 era Senador de Roma el noble Giambattista Fenzoni, renombrado jurista.

110 Presutti dice que, al entrar el estandarte en la iglesia, sonaron las trompetas y tambores del Popolo Romano [del ayuntamiento], y que se dispararon muchos cohetes. Lo recibió en la puerta principal el P. General de la Compañía, acompañado por otros miembros de la Curia y lo trasladaron hasta el altar mayor mientras sonaba la música (TACCHI VENTURI, Il fratel Antonio Presutti, p. 90).

111 GIGLI, Diario, p. 60-62. 
Los días siguientes se celebraron las correspondientes misas de acción de gracias por los nuevos santos: el lunes 14 de marzo en Santiago de los españoles en honor de san Isidro, con la presencia del embajador y sermón en español a cargo del dominico P. Mosero; el martes 15 en el Gesù en honor de san Ignacio y san Francisco Javier, predicando el General Vitalleschi con la asistencia de 24 cardenales; el miércoles 16 en Santa María della Scala en honor de santa Teresa, luciendo la iglesia ese día nuevas colgaduras e iluminación de velas por toda la cornisa; y el jueves 17 en la Chiesa Nueva, en honor de san Felipe Neri ${ }^{112}$. Todos los días acudieron los cardenales corporativamente en forma de capilla papal, y el mismo Gregorio XV tuvo a bien visitar todas y cada una de las iglesias; el día 19, fiesta de San José, celebró la Misa en la Chiesa Nuova, asistiendo 26 cardenales. El Oratorio organizó un octavario de acción de gracias teniendo el sermón cada día uno de los más ilustres predicadores del momento.

El día 22 de marzo el Papa bendijo las medallas conmemorativas acuñadas para la canonización. Pasada la Pascua, continuaron las celebraciones. El 16 de mayo los florentinos organizaron una solemne fiesta con vistosa procesión en honor de su paisano Felipe Neri, con su estandarte y reliquia bajo palio, que concluyó en la iglesia de San Juan de los florentinos, donde había residido el santo como capellán ${ }^{113}$.

Sin lugar a dudas, la magna procesión del 13 de marzo de 1622 constituyó una manifestación apoteósica y triunfal. Pero, más allá de todo el aparato escénico y festivo desplegado, de suyo efímero -como el fastuoso theatrum sacrum montado para la ceremonia-, que se inserta en la percepción tan típicamente barroca de la realidad como un gran teatro del mundo, la canonización de 1622 encierra otros significados e implicaciones, menos efímeros, estrechamente relacionados con la forma de entenderse a sí misma de la Iglesia post-tridentina y de presentarse ante el mundo.

\section{AD MAIOREM HISPANIAE GLORIAM?}

Durante su breve pontificado de poco más de dos años, pues fallecía el 8 de julio de 1623, Gregorio XV beatificó al reformador franciscano Pedro de Alcántara el 18 de abril 1622 y, algo menos de un mes antes, el 12 de marzo canonizó a los beatos Isidro, Ignacio de Loyola, Francisco Javier y Teresa de Jesús. Este fue, sin duda, uno de los días más memorables de su pontificado, por el que siempre se le recordará. En general, la interpretación más común que se ha ofrecido sobre esta canonización es la que ve en ella un reflejo del poderío español y su influencia en Roma. Marina Caffiero subraya «un preciso significado político relativo a la afirmación en Roma

112 BAV, Urb. Lat. 1091, f. 204v.

113 Carlo GASBARRI, L'Oratorio Romano dal cinquecento al novecento, Roma, 1963, pp. 24-25. 
de la autoridad y del poder tanto de España como de la «nación» española presente en la ciudad» ${ }^{114}$. No cabe duda de que esta significativa celebración creó un «clima de triunfo del partido español en Roma» ${ }^{115}$. Que existía dicho partido y actuaba es evidente, pero no lo es tanto que tuviera la fuerza que le atribuye Thomas Dandelet ${ }^{116}$ hasta el punto de hablar de la existencia de una Roma española, a partir del pontificado de Pío IV, idea cuestionada seriamente por Maria Antonietta Visceglia. Según esta autora, «Roma se convirtió en el escenario elegido por España para desplegar una ofensiva simbólica destinada a representar la dimensión universal alcanzada por la acción política de la Monarquía Católica en defensa de la fe y, al mismo tiempo, a forjar la imagen identitaria de una España fundada a partir de sus diferentes componentes nacionales» ${ }^{117}$. Y, en este sentido, las canonizaciones jugaban un destacado papel para la consecución de ambos objetivos. Máxime en un momento en el cual la potencia española comenzaba a declinar en un prolongado ocaso.

Al mismo tiempo, esta canonización de cuatro españoles reafirmaba el poderío simbólico frente a Francia, más importante si cabe por cuanto constituía la potencia emergente. La corte de París no quiso pasar desapercibida en una ocasión que se presentaba tan favorable a los intereses de España, y buscó las rendijas que le permitieran jugar algún papel, aunque fuera secundario. El pasado «francés» de Ignacio y Javier sirvieron bien para este propósito ${ }^{118}$. El rey Luis XIII, escrita de su puño y letra, y la reina enviaron sentidas cartas al Papa suplicando la canonización del beato Ignacio, que sentían suyo pues había sido miembro de la «honorable nación galicana» en la Facultad de Artes de la Sorbona ${ }^{119}$ y, sobre todo, porque en París había fundado la Compañía de Jesús. Lo mismo podía afirmarse de Francisco Javier, pero añadiendo que Su Majestad cristianísima seguía considerándose, pues nunca había renunciado al título, rey de Navarra. Los jesuitas vieron con agrado este posicionamiento tan favorable del monarca francés por la causa de sus santos que tan bien se integraba en su política

${ }^{114}$ Marina CAFFIERO, Instituzioni, forme e usi del sacro, en Giorgio CIUCCI (ed.), Roma moderna, Storia di Roma dall'antichità a oggi, Laterza, Roma-Bari, 2002, p. 147: «un preciso significato político relativo all'affermazione a Roma dell'autorità e del potere sia della Spagna che della 'nazione' spagnola presente in città».

115 Maria Antonietta VISCEGLIA, Guerra, diplomacia y etiqueta en la corte de los Papas (siglos XVI y XVII), Polifemo, Madrid 2010, p. 76.

116 Thomas Dandelet, Spanish Conquest and Colonization at the Center of the Old World: The Spanish Nation in Rome, 1555-1625, en The fournal of Modern History, 69/3 (1997), pp. 479-511; La Roma española (1500-1700), Crítica, Barcelona, 2002.

117 VISCEGLIA, Guerra, diplomacia y etiqueta, p. 97. Maria Antonietta VISCEGLIA, Roma papale e Spagna. Diplomatici, nobili e religiosi tra due corti, Bulzone Editore, Roma, 2010 pp. 32-34.

118 BAV, Boncompagni Ludovisi, E. 79, ff. 248-249v.

119 La organización interna de la Facultad distribuía a sus alumnos en cuatro «naciones»: la anglicana, la normanda, la picarda y la galicana, incluyendo esta última a los procedentes del sur de Francia, España, Italia y Grecia. 
de «desespañolizar» la Compañía. Y, de algún modo, tanto los nuevos santos jesuitas como el propio Felipe Neri constituyeron la «cuota» francesa de la canonización.

Porque, en efecto, tampoco debía olvidarse el parecer favorable de Felipe Neri a la aceptación por parte del papa de la sinceridad de la conversión del monarca francés Enrique IV. La postura filo francesa del fundador del Oratorio y de su discípulo predilecto y sucesor, el cardenal Baronio, era ahora recompensada con un apoyo explícito de Luis XIII a su canonización ${ }^{120}$.

En cualquier caso, la presencia del santo florentino en la canonización respondió a una razón estratégica ya que, vista la evolución de los acontecimientos, probablemente ni Gregorio XV ni la Congregación de Ritos quisieron una celebración exclusivamente española y, por eso, se le agregó en el último momento. «Si Felipe IV podía celebrar «lo splendor d'Iberia», o sea, la integración en el pantheon católico de un elevado número de santos españoles y obtener una legitimación sacral y celeste de su patronage terreno, también el Papa se ergía como indiscutible filtro de selección y de control de los factores simbólicos y legitimantes procurados por la santidad» ${ }^{121}$. La canonización servía, por tanto, para reforzar el papel del Papa como árbitro de las relaciones políticas entre las potencias cuando no faltaba mucho tiempo para que dicha función pontificia comenzara a cuestionarse.

No cabe, por tanto, negar una estrategia política en esta canonización múltiple donde la potencia hispana brillaba aun con poderío. El hecho meramente anecdótico de que el pueblo romano hablara mordazmente de la canonización de cuatro españoles y un santo evidencia su significado político, que hasta los protestantes pusieron de relieve con un juego de palabras muy poco sutil al atribuir la «canonizzazione» de Ignacio de Loyola a la amenaza de los «cannoni» españoles ${ }^{122}$. Pero, al mismo tiempo, resulta imposible reducir la canonización a unos límites estrictamente nacionales cuando el propio Gregorio XV al comunicar la canonización al rey de España indicaba expresamente, al menos de Ignacio y Francisco Javier, su cualidad de astros «non solum Hispani coeli, sed Catholicae Ecclesiae, et novi Orbis syderibus» ${ }^{123}$. Astros, por tanto, no solo del cielo hispano sino de toda la Iglesia.

120 ACOR, A IV 13, f. 198: Carta de la reina María de Medicis, fechada en París el 28/9/1610, urgiendo su canonización porque el santo «s' era mostrato affmo al ben di questo stato».

121 GOTOR, Chiesa e santità nell'Italia moderna, p. 56: «Se Filippo IV poteva celebrare "lo splendor d'Iberia", ossia, l'inserimento nel pantheon cattolico di un elevato numero di santi spagnoli e ottenere una legittimazione sacrale e celeste del suo patronage terreno, anche il papa si ergeva a indiscutibile filtro di selezione e di controllo dei fattori simbolici e ligitimanti procurati dalla santità». Una idea similar en CAFFIERO, Instituzioni, forme e usi del sacro, p. 147; y en Gaetano STANO, Il rito della beatificazione da Alessandro VII ai nostri giorni, en Miscellanea in occasione del IV Centenario della Congregazione per le Cause dei Santi (1588-1988), Città del Vaticano, 1988, pp. 368-369.

122 GOTOR, Chiesa e santità nell'Italia moderna, p. 55.

123 AAV, Arm XLV, 19, f. 254; Arm XLV, 22, f. 311v. 
Gotor habla del alto número de canonizaciones y beatificaciones de españoles durante el siglo XVII como «uno de los más sensibles indicadores religiosos y propagandísticos de la alianza política entre España y la Santa Sede» ${ }^{124}$. En este sentido, la canonización de 1622 puede entenderse, desde el punto de vista político, como uno de los momentos álgidos de la alianza entre el Papado y la Monarquía católica en el contexto de la Guerra de los Treinta Años (1618-1648), que resucitaba las luchas entre católicos y protestantes en el corazón de Europa. El primer periodo del conflicto se había saldado con el clamoroso triunfo de la Liga católica en la batalla de la Montaña Blanca ${ }^{125}$, cerca de Praga, el 8 de noviembre de 1620, que permitió la consolidación del catolicismo en Bohemia. La Liga evangélica quedó disuelta y las posesiones de Federico $\mathrm{V}$ en el Palatinado renano fueron confiscadas y el título de Elector Palatino se le concedió a uno de sus primos, el católico Maximiliano, duque de Baviera. La relación de la canonización con este esfuerzo militar por implantar el catolicismo en el corazón de Europa se prueba a partir del deseo manifestado por Gregorio XV de destinar el importe no invertido en los gastos de la ceremonia a este fin de alentar las campañas de la Liga católica. Los actores de la causa no se opusieron.

Con todo, y como acertadamente observa Visceglia, «el ascenso al empíreo de los santos de estas figuras no se puede achacar solo a las presiones de la Monarquía sino, sobre todo, a la fuerza de las órdenes y de las familias religiosas a las que pertenecían y al evidente reconocimiento de la acción misionera en el nuevo mundo que adquiere un puesto central en el relanzamiento de la soberanía universal del pontífice en la dimensión espiritual de la conquista de las almas» ${ }^{126}$.

124 GOTOR, Chiesa e santità nell'Italia moderna, p. 94: «uno dei più sensibile indicatori religiosi e propagandistici dell'alleanza política tra la Spagna e la Santa Sede».

125 Este triunfo tuvo también su vertiente simbólica con la confiscación de bienes, llevados a Roma, entre ellos numerosos códices de la biblioteca palatina de Heilderberg que fueron depositados en la Biblioteca Vaticana. El P. Domingo de Jesús María Ruzzola trajo a Roma un venerado icono de la Virgen, que había encontrado muy maltrecho en el castillo de Strakonitz, y que había utilizado para arengar a las tropas contra los protestantes iconoclastas antes de la batalla de la Montaña Blanca; a raíz del triunfo católico, comenzó a venerarse bajo la advocación de Nuestra Señora de la Victoria. Depositado en la basílica de Santa María la Mayor, el papa lo concedió a los carmelitas descalzos para su nueva iglesia, construida junto a las Termas de Diocleciano, que adoptó el mismo título, y hasta donde fue llevado en solemne procesión el 8 de mayo de 1622. Para dicha iglesia realizó Bernini unos años después, entre 1647 y 1651, su famosa escultura del éxtasis (o transverberación) de Santa Teresa.

126 VISCEGLIA, Roma papale e Spagna, 2010 p. 45-46: «l'ascesa nell'empireo dei santi di queste figure non è rapportabile solo alle presioni della Monarchia, ma piuttosto alla forza degli ordini e delle famiglie religiose di appartenenza e all'evidente riconoscimento dell'azione missionaria nel nuovo mondo divenuta centrale nel rilancio della sovranità universale del pontefice nella dimensione spirituale di conquista delle anime». 
En efecto, la canonización de Ignacio, Javier, Teresa y Felipe Neri muestra, por encima de todo, el enorme poder que habían adquirido sus propias familias religiosas. Gotor, a este propósito, no duda en afirmar que tiene «un valor periodizante en la historia de la santidad moderna porque fueron el fruto de un extraordinario impulso devocional a nivel local, organizado por las nuevas órdenes religiosas y por sus cardenales «protectores» en la curia, consiguiendo imponer su propia voluntad a la Santa Sede que habría preferido un mayor gradualismo y un mayor respeto de su autoridad a la hora de decidir» ${ }^{127}$. Y no sólo de la Santa Sede sino también del propio monarca español que tampoco deseaba esta canonización múltiple, como se ha visto más arriba ${ }^{128}$.

En esta auténtica carrera por la canonización de sus santos hubo ganadores pero también perdedores. Si la Compañía de Jesús se alzó con el primer puesto de forma indiscutible colocando no a uno sino a dos santos en este peculiar pódium, otras órdenes de gran abolengo resultaron claramente desfavorecidas. Una carta publicada por Cécile Vicent-Cassy refiere la amargura con la que fray Juan Belda, postulador de la causa del obispo agustino Tomás de Villanueva, se lamentaba de su exclusión en la gran canonización del 12 de marzo de 1622:

Nuestro $S^{\text {to }}$ a quedado afuera por pobre, que viviendo dio todo lo que tenía a los pobres i no se reservó nada para sí, i agora en esta ocasión tan buena i que el Papa le quería canonizar en compañía de los cincos $\mathrm{s}^{\text {tos }}$, por falta de dinero a quedado. Considere v. m. que día fue esta [sic] para mi, que no e llorado tanto en mi vida de ver que se canonizavan cinco $\mathrm{s}^{\text {tos }}$ que io tenía primero acabada la causa de nuestro Sto, primero que ellos, i a quedado sin canonizarse ${ }^{129}$.

Con todo, unas líneas más abajo abría una puerta a la esperanza porque «el Papa a prometido de canonizarnos al septiembre que viene a nuestro santo y al beato Beltrán y al beato Pascual Bailon y al beato Pedro de Alcántara y a un santo obispo florentino de la orden del Carmelo calzado ${ }^{130}$. Dicha canonización en el mes de

127 GOTOR, Chiesa e santità nell'Italia moderna, p. 65: «Le canonizzazioni del 1622 hanno un valore periodizante nella storia della santità moderna poiché furono il frutto di una straordinaria spinta devozionale a livello locale, organizata dai nuovi ordini religiosi e dai loro cardinali 'protettori' in curia, i quali riuscirono a imporre la propia volontà alla Santa Sede che avrebbe preferito più gradualismo e un maggior rispetto della sua autorità decisionale».

128 AHN, AMAE, Santa Sede, legajo 21, n. 321 (Felipe IV a Gregorio XV, 1 de noviembre de 1621).

129 Cécile VINCENT-CASSY, Luchar por su santo. Rivalidades entre las órdenes religiosas en torno a las canonizaciones en el siglo XVII, en José Luis BETRÁN MOYA, Bernat HERNÁNDEZ y Doris MORENO (eds.), Identidades y fronteras culturales en el mundo ibérico en la Edad Moderna, Universitat Autónoma de Barcelona, Bellaterra, 2016, p. 180. El original se encuentra en AHN, Diversos, colecciones, 16-1-6.

${ }^{130}$ Resulta muy interesante comprobar que, según Belda, el Papa promete canonizar pronto a otros cinco beatos, de los cuales uno es dominico (Luis Bertrán), otro agustino (Tomás de Villanueva), dos franciscanos reformados (Pascual Bailón y Pedro de Alcántara, este segundo promotor de la 
septiembre no se llevó a efecto. Más aun, el 16 de julio de 1622 Gregorio XV «iussit differri omnes canonizationes» ${ }^{131}$, es decir, dio orden al prefecto de la Congregación de paralizar el resto de causas correspondientes a siervos de Dios fallecidos recientemente, algunos de los cuales tenían ya el proceso concluido a falta tan sólo de fijar una fecha para la canonización, como en el caso de los beatos referidos por Belda ${ }^{132}$.

Durante los siguientes 35 años sólo hubo nueve canonizados y todos de época antigua ${ }^{133}$. Por otra parte, el Santo Oficio comenzó a regular más estrictamente las manifestaciones de culto profesadas públicamente a los difuntos muertos con fama de santidad, publicando en 1625 dos decretos sobre la materia que, junto con las normas dictadas por Urbano VIII, fijaron una praxis muy restrictiva cuya primera consecuencia fue la paralización de numerosas causas, algunas de ellas para siempre, señalando un plazo mínimo de cincuenta años que debían transcurrir entre la muerte del candidato a los altares y la apertura del correspondiente proceso.

Las restricciones pontificias, legisladas durante los varios lustros en que los papas no quisieron canonizar a ningún beato moderno, pueden ser consecuencia de los abusos anteriores, fueran estos reales o solamente percibidos como tales. Por poco espíritu crítico que se posea, es difícil observar el iter que llevaron las causas culminadas en 1622 sin advertir las enormes presiones a las que se vieron sometidos tanto Paulo V como Gregorio XV para que decretaran la glorificación de personas fallecidas pocos años antes: san Francisco Javier en 1552, san Ignacio en 1556, santa Teresa en 1582 y san Felipe Neri en 1595.

Se ha insistido mucho en las presiones externas ejercidas fundamentalmente por las cortes europeas para alcanzar la canonización de sus súbditos; en este sentido la insistencia de Felipe III resulta evidente. Pero, con toda probabilidad, los pontífices se vieron menos apremiados por dichas presiones externas que por las que se

reforma alcantarina dentro de su orden) y un carmelita calzado. Claramente se trataría de una canonización compensatoria en la que se reconocería el peso específico de las antiguas órdenes mendicantes (dominicos y franciscanos) frente a las nuevas congregaciones (Compañía de Jesús y Oratorio). Es muy claro en el caso de los carmelitas: a continuación de la canonización de la gran reformadora del Carmelo, se propone la de un obispo de la rama no reformada, o calzada, el beato Andrés Corsini. Si a origen geográfico nos referimos, de nuevo aparecen cuatro españoles y un florentino. Aunque en este hipotético caso, también quizás de modo compensatorio, de los cuatro españoles, tres pertenecían por un concepto u otro a la Corona de Aragón.

131 ACCS, Decreta Servorum Dei, I, p. 209. Unos meses antes, el 28 de mayo, la Congregación acordaba sondear la decisión del Pontífice sobre efectuar de manera inmediata la canonización de los beatos Pascual Baylon y Pedro de Alcántara (ibid., p. 207).

132 Cuya canonización sufrió un parón muy notable, con la única excepción del obispo carmelita Andrés Corsini (1302-1374) que fue canonizado en 1629 porque era un santo antiguo. Los beatos modernos tuvieron que esperar bastantes años: Tomás de Villanueva a 1658, Pedro de Alcántara a 1669, Luis Bertrán a 1671, y Pascual Baylon a 1690.

133 GOTOR, Chiesa e santità nell'Italia moderna, p. 65. 
ejercían al interior de la propia Iglesia. Acostumbrados al ejercicio de la diplomacia, los papas y sus cardenales nepotes fueron manejando los tiempos de acuerdo con sus conveniencias, cediendo cuando lo creían oportuno. Sin embargo, la labor continua de presión ejercida por las curias de los jesuitas, carmelitas y oratorianos tuvo que resultarles mucho más agobiante, por cuanto éstas no desaprovechaban ninguna ocasión para insistir utilizando hábilmente la influencia de sus amigos y protectores, fueron estos seglares o eclesiásticos, constituyendo verdaderos grupos de presión ${ }^{134}$. La estrategia adoptada por los cardenales Baronio y Bellarmino para promover simultáneamente la canonización de Felipe Neri e Ignacio de Loyola manifiesta de manera patente lo que venimos afirmando. Por ello no resulta extraño encontrar quejas más o menos veladas procedentes del pontífice y de los mismos responsables de la Congregación.

Por otra parte, fueron las órdenes religiosas fundadas por los nuevos santos las que sacaron mayor rendimiento a la canonización en cuanto vehículo promocional. A los pocos días de la celebración, el 17 de marzo de 1622, el P. Vitelleschi, Prepósito general de la Compañía, escribía al procurador de España relatándole sucintamente la apoteosis de las jornadas precedentes destacando que, entre todos los santos canonizados, «llevaron los coraçones los dos nuestros» ${ }^{135}$. Leyendo las relaciones de las fiestas posteriores a la canonización celebradas en Roma y, de modo muy particular, la procesión del 13 de marzo, no se advierte (al menos, a mí no me lo parece) una apoteosis de la nación española, «una síntesis del triunfalismo español» en palabras de Dandelet ${ }^{136}$, cuya presencia queda relegada al acompañamiento de san Isidro, sino más bien una apoteosis de la Compañía de Jesús, en primer lugar, y secundariamente del Oratorio y del Carmelo descalzo. Resulta muy significativo que, según refiere Gigli, el momento supremo de la procesión se alcanzara al llegar al Gesù, no solo por su magnificente decoración (en la que no había ni un solo elemento referido a España) sino porque allí se encontraban las principales autoridades de Roma ${ }^{137}$, el hermano del Papa y numerosos cardenales para recibir el estandarte de san Ignacio y san Francisco Javier. Es decir, Roma, el Papa y la Iglesia, en su más amplio sentido

${ }^{134}$ Peter BURKE, How to be a Counter-Reformation saint?, en Peter BURKE, The historical anthropology of early modern Italy. Essays on perception and communication, Cambridge, 1987, pp. 58-59; Simon DitCHFIELD, Coping with the Beati Moderni: Canonization Procedure in the Afthermath of the Council of Trent, en Thomas M. MCCOOG (ed.), Ite inflammate omnia. Selected historical papers from conferences held at Loyola and Rome in 2006, Institutum historicum Societatis Iesu, Roma, 2010, p. 425.

135 BNE, Mss/18168: Papeles de Gil González Dávila.

136 DANDELET, La Roma española, p. 228.

${ }^{137}$ Lo que no deja de resultar sorprendente dada la integración plena de Felipe Neri en la sociedad romana de su tiempo y su popularidad, desde luego mucho mayor que la de Ignacio de Loyola. De algún modo, en este día de triunfo la habilidad para las relaciones institucionales de la Compañía logró que san Ignacio pareciera más romano que el romanaccio Filippo Neri. 
universalista ${ }^{138}$. Representación simbólica que no se daría en los otros casos, reducidos a dimensiones mucho más modestas y locales: los carmelitas con santa Teresa, los florentinos con san Felipe y los españoles con san Isidro. Incluso desde un punto de vista puramente espacial, la iglesia de Santiago de los españoles, ámbito eclesiástico propio de la nación española en Roma, solo acogió las celebraciones en honor de san Isidro porque tanto los santos jesuitas como la santa carmelita, aun siendo españoles, tenían «su propia casa» en Roma en las residencias de sus respectivas instituciones. De igual modo, el protagonismo alcanzado por san Isidro y el embajador de Su Majestad Católica en la ceremonia de la canonización queda por completo diluido en la procesión del día 13, a la que asistió toda Roma, donde son los dos nuevos santos jesuitas los que adquieren el máximo relieve gracias a la magnificencia desplegada, empleada por la Compañía con gran habilidad como eficacísima estrategia propagandística.

De igual modo, las fiestas organizadas a lo largo y ancho de la Cristiandad en los meses siguientes pusieron de manifiesto no solo el júbilo despertado en la Iglesia por estos nuevos santos sino, principalmente, el poder alcanzado por sus correspondientes congregaciones y, de modo muy singular, por la Compañía de Jesús, que no escatimó gasto alguno (a pesar de las órdenes del General llamando a la moderación ${ }^{139}$ ) para organizar unas celebraciones de acción de gracias espectaculares, probablemente como no se habían visto con anterioridad ${ }^{140}$.

Durante el proceso de canonización de san Ignacio, la Compañía redefinió la proyección de su fundador en la línea de primar su dimensión romana y, por tanto, universal. Las fiestas de la canonización cumplieron una misión muy señalada al asentar este nuevo perfil del santo. Como afirma Jiménez Pablo, «sin ninguna duda, la imagen del Ignacio de Loyola que subió a los altares fue la apoyada por la monarquía francesa y el Papado, alejada de sus orígenes hispanos». No se trata de «la glorificación de un San Ignacio armado con la espada y el escudo que en vida había sido combativo con la herejía y, en calidad de santo 'hispano', representaba un papel de garante del catolicismo, reflejo de (...) una Monarquía hispana ofensiva con la herejía. En la práctica, esta imagen de santidad, chocaba con los intereses religiosos del Papado que apoyaba el nuevo modelo de santidad piadosa y austera

138 Representada en una de las dos grandes estatuas alegóricas situadas en la fachada del Gesù; la otra representaba la Iglesia de Japón surgida gracias al misionero Xavier.

139 Monumenta Ignatiana, Series IV, vol. II, p. 980.

140 Eliseo SERRANO MARTíN, «Annus Mirabilis». Fiestas en el mundo por la canonización de los jesuitas Ignacio y Francisco Favier en 1622, en José Luis BETRÁN (ed.), La Compañia de Jesús y su proyección mediática en el mundo hispánico durante la Edad Moderna, Sílex, Madrid, 2010, pp. 297-343; Cristina OSSWALD, Aspectos de autoridad y poder en las ceremonias de canonización de Ignacio de Loyola y Francisco favier en Portugal, en Hipogrifo, 1/1 (2013), pp. 43-55. 
que se había impuesto en Roma, con un Ignacio de Loyola cercano a los pobres y enfermos, reflejo de la imagen de pobreza que proyectaban Felipe Neri y Carlos Borromeo» ${ }^{141}$.

Este replanteamiento nos acerca mucho más a la clave que entendemos ha de ser crucial para graduar el acontecimiento de la canonización en su justa medida. Dicha clave no sería tanto la política cuanto la propiamente eclesial. Ya afirmaba Caramuel que la canonización no es una mera victoria política sino un triunfo a la vez celeste y terreno por cuanto exalta a la gloria del cielo a ciudadanos de la Iglesia peregrinante $^{142}$. La respuesta del embajador español, marqués de Castelrodrigo, a Urbano VIII: «Los santos no son de ninguna nación», su patria es el cielo, puede ayudar a calibrar mejor la importancia relativa del pretendido nacionalismo español en esta canonización ${ }^{143}$.

Por tanto, se hace preciso plantear una interpretación polivalente para la gran canonización de 1622, con diversos niveles de lectura convergentes, que se solapan entre sí.

Sin duda, fue un día de gloria para la nación española no solo en Roma ${ }^{144}$ sino en todo el orbe, que contribuyó poderosamente a solidificar los sentimientos de unidad en torno a las figuras insignes de cuatro de sus súbditos ${ }^{145}$. Pero, desde luego en ningún caso puede interpretarse como «una glorificación de la Monarquía de la que

141 Esther JimÉNEZ PABLO, La canonización de Ignacio de Loyola (1622): Lucha de intereses entre Roma, Madrid y París, en Chronica Nova, 42 (2016), pp. 88-89.

142 Caramuelis, Dominicus. Hoc Est, p. 389.

143 AGS, Estado, leg. 3842, f. 181. Cit. por José Luis COLOMER, Luoghi e attori della pietas hispanica a Roma all'epoca di Borromini, en Christoph Luitpold FrOMMEL y Elisabeth SLADECK (dirs), Francesco Borromini. Atti del convegno internazionale, Electa, Milano, 2000, p. 357, nota 21.

144 Aunque no para todos los españoles. Recúerdense, por vía de ejemplo, las lágrimas del P. Belda: «No he llorado tanto en mi vida» (cfr. nota 129). Buen indicio de que el triunfo más que de la nación fue de las congregaciones que vieron culminado el deseo de canonizar a sus santos.

${ }^{145}$ Si bien, en una nación todavía poco consolidada como era por entonces España, donde cada reino seguía manteniendo una gran autonomía y su personalidad propia, cabe cuestionar el calado de cada uno de los nuevos santos más allá de sus lugares originarios. La canonización de san Isidro alcanzó, en este sentido, una repercusión puramente local en Madrid y su devoción prácticamente quedó reducida a la capital. El reino de Navarra festejó a su paisano san Francisco Javier y, no sin oposición, le nombró copatrón junto con san Fermín. De igual forma, la provincia de Guipúzcoa eligió por patrón a san Ignacio (al igual que posteriormente la de Vizcaya por carecer de un santo de la tierra, pero no así la de Álava). Las cortes de Castilla votaron por copatrona a santa Teresa junto con el apóstol Santiago, pero los detractores de la extensión del patronazgo de la santa abulense insistieron en que se reducía a dicho reino y no se extendía, por tanto, a los otros de la Península ni tampoco a los territorios americanos. Se ve, por tanto, que en el fondo existe un sentimiento genérico de pertenencia de dichos santos a la nación española, pero su vinculación con los diversos territorios resultaba muy desigual. Sin olvidar, por otro lado, la ausencia en dicha canonización de santos oriundos de la Corona de Aragón. 
provenían» ${ }^{146}$. Ni, por otra parte, debe olvidarse, como advierte Copeland, que «los santos tenían ciertamente el potencial de representar áreas geográficas o grupos de personas, pero su significado estuvo siempre abierto al cambio pudiendo no ser identificados prioritariamente por todos en términos locales, regionales o nacionales» ${ }^{147}$. Lo que creemos fue evidente en el caso de los dos santos jesuitas e incluso, aunque en mucha menor medida, en el de santa Teresa.

Podría entenderse que la canonización supuso un reconocimiento, más que a la nación originaria de los santos, al papel desarrollado por la Iglesia española, especialmente en los recientes tiempos de la violenta sacudida provocada por la Reforma protestante, así como en la labor evangelizadora de nuevos continentes. En efecto, aquel día «la España religiosa moderna [pudo] contempla[rse] en el espejo de sus santos» ${ }^{148}$. Siendo así que también fue un reconocimiento para la Iglesia italiana. De hecho, los santos canonizados durante el siglo XVII son, en su gran mayoría, españoles e italianos, «las dos naciones que más se empeñaron, en el siglo XVI, en la reforma católica» ${ }^{149}$. Delooz afirmó rotundamente que el XVII es «le siècle des canonisations espagnoles» ${ }^{150}$ mientras que Armogathe ha hablado de «le Siècle d'or de la saintité espagnole» ${ }^{151}$. Lo cual resulta cierto, pero no lo es menos que también lo fue de la santidad italiana y con mayor razón. El gran número de santos canonizados procedentes de ambos territorios es una prueba más de la intensidad con que se desarrolló en ellos la Reforma Católica. Y, en este sentido, sí es posible afirmar que esta canonización reflejaba «la posición central que ocupaban los santos españoles en la Iglesia militante y el triunfo de la Reforma Católica» ${ }^{152}$.

De forma muy notoria, la canonización de 1622 constituyó una prueba evidente de la potencia alcanzada, en relativo poco tiempo, por las nuevas fuerzas vivas de la Reforma Católica. Dicthfield señala, a este propósito, que los santos canonizados constituyen «los más afamados símbolos del renacimiento de la Iglesia Católica Romana» ${ }^{153}$.

146 JiMÉNEZ PABLO, La canonización de Ignacio de Loyola (1622), p. 102.

147 Copeland, Spanish Saints in Counter-Reformation Italy, p. 104: «saints certainly held the potential to represent geographical areas or groups of people, but their significance was always open to change and they might not be identified by all primarily in local, regional or even national terms».

${ }^{148}$ Jean-Robert ARMOGaTHE, La fabrique des saints. Causes espagnoles et procédures romaines d'Urbain VIII à Benoît XIV (XVII'-XVIII siècles), en Mélanges de la Casa de Velázquez, 33-2 (2003), p 26.

149 PAPA, Le cause di canonizzazione, p. 145: «le due nazioni che più si erano impegnate, nel cinquecento, nella reforma cattolica».

150 Pierre Delooz, Sociologie et canonisations, Martinus Nihoff, Le Haye, 1969, p. 252.

151 ARMOGATHE, La fabrique des saints, p. 15.

152 DANDELET, La Roma española, 229.

153 Ditchield, Coping with the Beati Moderni, p. 414: «the... more famous symbols of Roman Catholic revival». 
No cabría mejor estrategia de propaganda o de imagen, utilizando términos contemporáneos, que la canonización de sus fundadores para reafirmar la importancia que habían adquirido dentro de la Iglesia. Y la brillantez con que se hizo contribuyó aún más a reforzar esta impresión.

Pero, por encima de todo, significó la visualización del triunfo de la Reforma Católica y de sus protagonistas ${ }^{154}$. Como señala Massimo Leone, «tras sesenta años de vigencia de las iniciativas tomadas en el concilio de Trento, la Iglesia Católica presentaba una nueva y restaurada imagen de sí misma a todos los creyentes del mundo y, al mismo tiempo, proponía nuevos modelos vivientes de perfección espiritual para el futuro de la Iglesia ${ }^{155}$. Podría decirse que fue un día de gloria para la Iglesia triunfante (no solo en el cielo sino también en la tierra) siguiendo la ingeniosa intuición de Po Chia ${ }^{156}$.

La enorme fuerza simbólica concentrada en esta canonización puede desplegarse igualmente por medio del análisis semiótico de cada uno de sus protagonistas. Así, san Ignacio representaría la fuerza aportada por las nuevas congregaciones de clérigos regulares; santa Teresa, el éxito de la reforma en las antiguas órdenes religiosas; san Francisco Javier, el ardor misionero con que la Iglesia Católica se expandió por los todos los confines del planeta; san Felipe Neri, la vitalidad de un clero secular reformado; y san Isidro, la participación del pueblo fiel en esta empresa común de la Reforma Católica, anclada en la mejor tradición de la Iglesia medieval.

Queda integrada, por tanto, en esta canonización de 1622, la representación del pueblo fiel, de la vida consagrada y del clero secular. Solo podría objetarse la ausencia de un obispo para completar la totalidad de la estructura eclesial ${ }^{157}$. Dicho obispo no es otro, a mi parecer, que san Carlos Borromeo, que se anticipó a esta canonización colectiva unos pocos años porque, si se comprueba, la suya fue la última canonización realizada antes de la que estamos estudiando, el 1 de noviembre de 1610. Esta asociación entre el santo arzobispo de Milán y los santos canoniza-

${ }^{154}$ Ya lo sugiere TURCHINI, La fabbrica di un Santo, p. 11: «Il santo, cui dovrebbe uniformarsi la regia, viene osannato in sordina: non è di lui che si trata, bensí della potenza della chiesa della Controriforma».

155 LEONE, Saints and Signs, p. 9: «after sixty years since the iniciatives taken at the Council of Trent, the Catholic Church presented a new and restored imagen of itself to all believers of the world and at the same time proposed new living models of spiritual perfection for the future of the Church».

156 Ronnie Po-CHIA HSIA, El mundo de la renovación católica, 1540-1770, Akal, Tres Cantos (Madrid), 2010, p. 65. Este ensayo es muy sugerente si bien contiene errores y lagunas notables, y la versión castellana desmerece por su deficiente traducción.

${ }^{157}$ Que podría haberse dado en el caso de haber agregado a esta canonización al ejemplar arzobispo de Valencia, el agustino Tomás de Villanueva (1486-1555), prototipo igualmente de prelado reformado conforme a los decretos tridentinos. 
dos en 1622, especialmente san Ignacio y san Felipe Neri, la advirtió ya el cardenal Baronio, que en 1602 relacionaba las dificultades surgidas en torno al culto tributado a su fundador, todavía no beatificado, un «negocio de tanta importancia con el que va unido el del beato Ignacio y el del ilustrísimo beato Borromeo», que tampoco estaban beatificados, a pesar del título que les da, según era costumbre. Como indica Gotor, «la misiva de Baronio es significativa en cuanto que revela que las causas de canonización de Felipe Neri, Ignacio de Loyola y Carlos Borromeo fueron vistas por los protagonistas de entonces como un único «negotio» ${ }^{158}$. Tanto el cardenal oratoriano como el jesuita Roberto Bellarmino se empeñaron en promover las tres causas al unísono, incluso mediante refinadas técnicas de propaganda ${ }^{159}$. Desde esta perspectiva, podemos hablar de una continuidad entre ambas canonizaciones, que mutuamente se complementan y completan ofreciendo, como señala Caffiero «de la manera más eficaz los modelos... de la santidad moderna ${ }^{160}$. Unos modelos que, independientemente del origen geográfico y de las características peculiares de cada uno de ellos, pretenden ser válidos para toda Iglesia universal ${ }^{161}$.

Por todo ello, la de 1622 fue «una canonización simbólica no del pasado sino del presente de la Iglesia» y «una síntesis de los primeros resultados de la Reforma Católica así como un indicador de sus propuestas» ${ }^{162}$. Es decir, constituyó no solo la canonización de los protagonistas de la Reforma Católica sino de la propia Reforma Católica.

158 GOTOR, I beati del Papa, p. 56: «negotio di tanta importantia con il quale va congiunto quello del beato Ignatio et del beato illustrissimo Borromeo». «La missiva di Baronio è significativa in quanto rivela che le cause di canonizzazione di Filippo Neri, di Ignazio di Loyola e di Carlo Borromeo furono vissute dai protagonista di allora como un unico 'negotio'». Resultaría muy interesante, aunque excede nuestro propósito, comprobar las relaciones existentes entre los tres santos, tanto por lo que respecta a los datos aparecidos en sus correspondientes bio-hagiografías, cuanto a la expansión de su culto y la iconografía, con lienzos y grabados en los que aparecen los tres o, al menos, dos de ellos (san Carlos y san Ignacio, san Carlos y san Felipe, san Ignacio y san Felipe). En este sentido resulta interesante Juan Eusebio NiEREMBERG, Vida del patriarca San Ignacio de Loyola fundador de la Compañia de Fesus. Resumida, y añadida de la Bula, y Relaciones de su Canonizacion, y de otros graves Autores, Zaragoza: En el Hospital Real y General de Nuestra Señora de Gracia, 1631, p. 115.

159 GOTOR, Chiesa e santità nell'Italia moderna, p. 50.

160 CAFFIERO, Instituzioni, forme e usi del sacro, p. 143: «nella manera più efficace i modelli... della santità moderna».

161 Giulio SoDANO, Modelli e selezione del Santo moderno. Periferia napoletana e centro romano, Liguori Editore, Napoli, 2002, pp. 20-21.

162 LEONE, Saints and Signs, p. 9: «a symbolic canonization not of the past, but of the present of the Church»y «a synthesis of the first results of the Catholic Reformation and a display of its proposals». 


\section{REFERENCIAS BIBLIOGRÁFICAS}

\section{a) Fuentes manuscritas}

Archivio Apostolico Vaticano (AAV)

- Acta Camerarii, 15 (1615-1624).

- Arm XLV, 19-22.

- Cong. Riti, n. 3192.

- Cong. Riti, nn. 3156-3157.

- Fondo Borghese, serie II, 422.

Archivio della Congregazione delle Cause dei Santi (ACCS)

- Decreta Servorum Dei, vol. I (1592-1654).

- Decreta Congregationis Sacrorum Rituum (1610-1621) (1622-1626).

Archivio della Congregatione dell'Oratorio di Roma (ACOR)

- A IV 13.

- A IV 14.

Biblioteca Apostólica Vaticana (BAV)

— Bar. lat. 2774 (san Francisco Javier).

— Bar. lat. 2786 (san Ignacio).

— Bar. lat. 2791 (Santa Teresa).

— Bar. lat. 2817.

- Bar. lat. 14085 (san Felipe Neri).

— Bar. lat. 14089 (san Isidro).

— Boncompagni E 69.

- Boncompagni-Ludovisi E 78.

- Boncompagni-Ludovisi E 79.

— Ott. lat. 467, I y II.

— Urbin. lat., cod. 1091.

— Urbin. lat., cod. 1092.

— Urbin. lat., cod. 1093.

- Vat. lat. 6321.

— Vat. lat. 8388.

- Vat. lat. 10742.

- Vat. lat. 12229.

- Vat. lat. 14085.

— Vat. lat. 14086.

Archivo General de Simancas (AGS)

— Estado, leg. 1001

— Estado, leg. 1867

— Estado, leg. 2994.

— Estado, leg. 3842.

Archivo Histórico Nacional (AHN)

- Archivo Ministerio de Asuntos Exteriores, Santa Sede, leg. 21.

- Diversos, colecciones, 16-1-6. 
Biblioteca Nacional de España (BNE)

- Mss/7326.

- Mss/8408.

- Mss/9716.

— Mss/12032-12037.

- Mss/18168.

- Mss/1871.

- Mss/2232.

- VC/1014/84.

b) Fuentes impresas

Acta Sanctorum, Julii VII, 29-31, Apud Jacobum du Moulin, Anturpiae 1731, 608-628. Acta Sanctorum, Octobris VII, 15-16, Typis Alphonso Greuse, Bruxelles 1845, 353-421. Acta Sanctorum, Maii III, 12-16, Apud Victorem Palmé, Parisis et Romae, 1866, pp. 509-546. Beatae virginis Teresine vitae, virtutum, ac miraculorum relationes SS.D.N. Paulo papae V per Sacrae Rotae auditores deputatos factae ad solemnem canonizationem, Barcinonae, apud S. Liberôs, 1621.

Alfonso MANZANEDo, Compendio della vita della serafica vergine S. Teresa di Giesu, gloria dell'antica Religione della Madonna del Carmine e Fondatrice de Padri e Monache Scalze del medemo Ordine, Per Vitale Mascardi, Roma 1647.

ANTONIO DE SAN JOAQUÍn, OCD, Año Teresiano: diario historico, panegyrico moral, en que se descriven las virtudes, sucessos, y maravillas de... Sta. Teresa de fesus, assignadas a todos los dias de los meses en que sucedieron..., t. III, En la Imprenta y Librería de Manuel Fernández, Madrid 1738.

BENEDICTUS XIV (Próspero LAMBERTINI), De servorum Dei beatificatione et beatorum canonizatione, Librería Editrice Vaticana, 2010-1018.

Breve relacion de las ceremonias hechas en la Canonizacion de los Santos Isidoro Labrador, Ignacio de Loyola, Francisco Xauier, Teresa de Iesus y Filipe Neri, Canonizados por la Santidad de nuestro muy Santo Padre Gregorio Papa XV, en 12 dias del mes de Março, año de 1622. En Madrid por Luis Sánchez.

Copia de unas cartas de los Padres de la Compañia de Iesus fechas en Roma a 21 de março, escritas a los Padres de Castilla, en que se da cuêta de lo sucedido en las canonizaciones de los cinco santos Isidro, Ignacio, Francisco, Teresa, y Filipo, hechas por nuestro muy S.P. Gregorio XV a doze de março de 1622, con dos insignes milagros que sucedieron en el mismo tiempo de su canonizacion, a intercession de los dos gloriosos santos san Ignacio, y san Francisco Xauier, Ympresso en Seuilla por Matias Clauijo..., 1622.

Di S. Diego de S. Nicolo del Puerto, o, de Alcala di Henares, dell'ordine di S. Franc. dell'Osseruanza, Per Francesco Zannetti, Roma 1588.

Giacinto Gigl, Diario Romano (1608-1670), a cura di Giuseppe Ricciotti, Tumminelli Editore, Roma, 1958. Otra edición, a cura di Manlio Barberito, Editore Colombo, Roma 1994. 
GIOVANNI BRICCIO, Relatione sommaria del solenne apparato, e ceremonia fatta nella Basilica di S. Pietro di Roma, per la canonizatione de gloriosi Santi Isidoro di Madrid, Ignatio de Lojola, Francesco Xauerio, Teresa Di Giesu, e Filippo Nerio Fiorentino, canonizati dalla Santità di N. S. Papa Gregorio XV à dì 12 di marzo MDCXXII, Per Andrea Fei, Roma, 1622.

- Relatione della solenne processione fatta in Roma, nella trasportatione de' stendardi de' gloriosi Santi, Isidoro de Madrid, Ignatio Loyola, Francesco Xaverio, Teresia de Giesu, et Filippo Neri Fiorentino, dalla Basilica di S. Pietro alle loro chiese particolari, con la descrittione dell'apparati \& feste fatte en dette chiese, of e altri luoghi..., Roma, 1622.

Joannes Caramuelis, Dominicus. Hoc est, Venerabilis P. Dominici a fesu-Maria, Parthenii Ordinis Carmelit. Excalceat. Generalis, virtutes, labores, prodigia, ecstases, et revelationes quibus lectorum instituitur ingenium, et voluntas formatur; est opus universis ascetis \& contemplativis..., Cosmerovius, Viennae in Austria, 1655.

José DE SANTA TeReSA, OCD, Reforma de los Descalzos de Nuestra Señora del Carmen de la primitiva observancia hecha por santa Teresa de Jesús en la antiquíssima Religión, fundada por el gran Profeta Elías, t. IV, Por Jualián de Paredes, impresor de libros, Madrid 1684.

JuAn Eusebio Nieremberg, Vida del patriarca San Ignacio de Loyola fundador de la Compañia de Jesus. Resumida, y añadida de la Bula, y Relaciones de su Canonizacion, y de otros graves Autores, Zaragoza: En el Hospital Real y General de Nuestra Señora de Gracia, 1631.

MELCHIOR RAMIREZ DE LEÓN, Relatione sommaria della vita, santità, miracoli et atti della canonizatione di S. Isidoro Agricola, patrone, e protettore della villa di Madrid..., Roma, A. Zannetti, 1622.

Monumenta Ignatiana, ex autographis vel ex antiquioribus exemplis collecta, serie IV, II, Madrid 1918.

PEDRO DE RIBADENEYRA, Relacion de lo que ba sucedido en el negocio de la Canonizacion del bienaventurado P. Ignacio de Loyola, fundador de la Religion de la Compañia de Jesus. Y de lo que acerca de su beatificacion ba becho la Santidad de nuestro señor Paulo Papa V este año de 1609, Madrid, 1609.

Relatio facta in consistorio secreto coram s.d.n. Gregorio Papa XV a Francisco Maria episcopo portvensi s.r.e. card. a Monte die xix. ianuarii m.dc.xxii. super vita, sanctitate, actis Canonizationis, of miraculis beati Ignatii fondatoris Societarie Iesu, Romæ, Apud Hæredem Bartholomæi Zannetti. Anno m.dc.xxii.

Relatio facta in consistorio secreto coram S.D.N. Gregorio papa 15. a Francisco Maria episcopo Portuensi S.R.E. card. a Monte die 24. Ianuarii 1622. super vita, sanctitate, actis canonizationis, \& miraculis beati Francisci Xavier e Societate Iesu, Romæ, Apud Hæredem Bartholomæi Zannetti. Anno m.dc.xxii

Relatio facta in consistorio secreto coram S.D.N. Gregorio papa 15. a Francisco Maria episcopo Portuensi S.R.E. card. a Monte Die 19. Ianuarij 1622. super vita, sanctitate, actis canonizatione, \& miraculis beati Isidori Agricolae de Matrito, Romæ, Apud Hæredem Bartholomæi Zannetti. Anno m.dc.xxii.

Relatio facta in consistorio secreto coram s.d.n. Gregorio papa 15. a Francisco Maria episcopo Portuensi S.R.E. card. a Monte die 24. Ianuarij 1622. super vita, sanctitate, actis canonizationis, of miraculis Beati Philippi Nerij Florentini Congregationis Oratorij fundatoris, Romæ, Apud Hæredem Bartholomæi Zannetti. Anno m.dc.xxii. 


\section{c) Bibliografía}

AGRESTI, Alessandro, Le canonizzazioni come impulso alla produzione artistica nella Spagna del XVII secolo, en Alessandra ANSELMI (ed,), I rapporti tra Roma e Madrid nei secoli XVI e XVII: arte diplomazia e politica, Gangemi, Roma, 2014, pp. 557-582.

ANSELMI, Alessandra, Roma celebra la monarchia spagnola: il teatro per la canonizazione di Isidoro Agricola, Ignazio di Loyola, Francesco Saverio, Teresa di Gesù e Filippo Neri (1622), en José Luis COLOMER (ed.), Arte y diplomacia de la Monarquía Hispánica en el siglo XVIII, Madrid, 2003, pp. 221-246.

ARMOGATHE, Jean-Robert, La fabrique des saints. Causes espagnoles et procédures romaines d'Urbain VIII à Benoît XIV (XVII -XVIII siècles), en Mélanges de la Casa de Velázquez, 33-2 (2003), pp. 15-31. Versión en español: La fábrica de los santos: causas españolas y procesos romanos de Urbano VIII a Benedicto XIV (siglos XVII-XVIII), en Homenaje a Henri Guerreiro: la bagiografía entre historia y literatura en la España de la Edad Media y del Siglo de Oro, Biblioteca Aurea hispánica 34, Iberoamericana Vervuert, 2005, pp. 149-168.

AZZOLINI, Ilario M., Quanto fu speso per la solennità della Canonizzazione dei ss. Ignazio e Francesco?, en La canonizzazione dei santi, pp. 127-129.

BURKE, Peter, How to be a Counter-Reformation saint?, en Peter BURKE, The historical anthropology of early modern Italy. Essays on perception and communication, Cambridge, 1987, pp. 4862.

CAFFIERO, Marina, Instituzioni, forme e usi del sacro, en Giorgio CIUCCI (ed.), Roma moderna, Storia di Roma dall'antichità a oggi, Laterza, Roma-Bari, 2002, pp. 143-180.

COLOMER, José Luis, Luoghi e attori della pietas hispanica a Roma all'epoca di Borromini, en Christoph Luitpold Frommel y Elisabeth SLADECK (dirs), Francesco Borromini. Atti del convegno internazionale, Electa, Milano 2000, pp. 346-357.

COPELAND, Clare, Spanish Saints in Counter-Reformation Italy, en Piers BAKER-BATES y Miles Pattenden (eds.), The Spanish Presence in Sixteenth-Century Italy: Images of Iberia, Farnham, 2015, pp. 102-123.

Dandelet, Thomas, Spanish Conquest and Colonization at the Center of the Old World: The Spanish Nation in Rome, 1555-1625, en The Journal of Modern History, 69/3 (1997), pp. 479511.

DANDELET, Thomas, «Celestiali eroi» e lo «splendor d'Iberia». La canonizzazione dei santi spagnoli a Roma in età moderna, en Giovanna FIUME (ed.), Il santo patrono e la città. San Benedetto il Moro: culti, devozioni, strategie di età moderna, Venecia, 2000, pp. 183-198.

- La Roma española (1500-1700), Crítica, Barcelona, 2002.

Ditchfield, Simon, Coping with the Beati Moderni: Canonization Procedure in the Afthermath of the Council of Trent, en Thomas M. MCCOOG (ed.), Ite inflammate omnia. Selected bistorical papers from conferences beld at Loyola and Rome in 2006, Institutum historicum Societatis Iesu, Roma, 2010, pp. 413-439.

DeloOZ, Pierre, Sociologie et canonisations, Martinus Nihoff, Le Haye, 1969.

DomenICI, Giuseppe, La glorificazione di Sant'Ignazio di Loyola e di San Francesco Saverio, en La canonizzazione dei santi, pp. 7-29.

FAgIOLO DELL'ARCO, Maurizio y CARANDINI, Silvia, L'effimero barocco. Strutture della festa nella Roma dell'600, Bulzoni, Roma, 1977. 
GIORDano, Silvano, Domenico di Gesù Maria Ruzola (1559-1630). Un carmelitano scalzo tra politica e riforma nella chiesa post-tridentina, Institutum Historicum Teresianum, Roma, 1991.

GOTOR, Miguel, I beati del Papa. Santità, Inquisizione e obbedienza in età moderna, Leo S. Olschki, Florencia, 2002.

- Chiesa e santità nell'Italia moderna, Laterza, Roma-Bari, 2004.

- Le canonizzazioni dei santi spagnoli nella Roma barocca, en Carlos José HERNANDO SÁNCHEZ (coord.), Roma y España un crisol de la cultura europea en la Edad Moderna, vol. 2, Sociedad Estatal para la Acción Cultural Exterior, Madrid 2007, pp. 621-639.

JiMÉNEZ PABLO, Esther, La canonización de Ignacio de Loyola (1622): Lucha de intereses entre Roma, Madrid y París, en Chronica Nova, 42 (2016) pp. 79-102.

LEONE, Massimo, Saints and Signs. A Semiotic Reading of Conversion in Early Modern Catholicism, Walter de Gruyter, Berlin-New York, 2010.

MARTíneZ Millán, José, Transformación y crisis de la Compañia de Jesús (1578-1594), en Flavio RURALE (coord.), I religiosi a corte. Teologia, politica e diplomazia in Antico regime, Bulzoni, Roma 1998, pp. 101-125.

NOYES, Ruth S., On the Fringes of Center: Disputed Hagiographic Imagery and the Crisis over the Beati moderni in Rome ca. 1600, en Renaissance Quarterly, 64/3 (2011), pp. 800-846.

Osswald, Cristina, Aspectos de autoridad y poder en las ceremonias de canonización de Ignacio de Loyola y Francisco Favier en Portugal, en Hipogrifo, 1/1 (2013), pp. 43-55.

PAPA, Giovanni, Le cause di canonizzazione nel primo periodo della Congregazione dei Riti (15881634), Urbaniana University Press, Roma, 2001.

PAVONE, Sabina, I gesuiti dalle origini alla soppressione, Laterza, Bari-Roma, 2013, pp. 33-44

Po-CHIA Hsia, Ronnie, El mundo de la renovación católica, 1540-1770, Akal, Tres Cantos (Madrid), 2010.

RIO BARREDO, María José del, Literatura y ritual en la creación de una identidad urbana: Isidro, patrón de Madrid, en Edad de Oro XVII (1998), pp. 149-168.

- Agiografia e cronaca di una capitale incerta (Madrid e Isidro Labrador, 1590-1620), en Giovanna FIUME (ed.), Il santo patrono, pp. 45-67.

Rowe, Erin Kathleen, Saint and nation. Santiago, Teresa of Avila, and plural identities in early modern Spain, The Pennsylvania State University Press, University Park, Penn, 2011.

Serrano Martín, Eliseo, Annus Mirabilis. Fiestas en el mundo por la canonización de los jesuitas Ignacio y Francisco favier en 1622, en José Luis BETRÁN (ed.), La Compañia de Jesús y su proyección mediática en el mundo hispánico durante la Edad Moderna, Sílex, Madrid 2010, pp. 297-343.

SoDano, Giulio, Modelli e selezione del Santo moderno. Periferia napoletana e centro romano, Liguori Editore, Napoli 2002.

STANO, Gaetano, Il rito della beatificazione da Alessandro VII ai nostri giorni, en Miscellanea in occasione del IV Centenario della Congregazione per le Cause dei Santi (1588-1988), Città del Vaticano, 1988, pp. 367-422.

TACChI Venturi, Pietro, Il Concistoro del 16 febbraio 1622, en La canonizzazione dei santi, pp. 34-49.

- La canonizzazione e la processione dei cinque Santi negli scritti e nei disegni di due contemporanei (Giovanni Bricci, Paolo Guidotti Borghese), en La canonizzazione dei santi, pp. 50-72.

\section{0}


- Le feste della canonizzazione nell'inedita Memoria di Giacinto Gigli e negli Avvisi, en La canonizzazione dei santi, pp. 73-80.

- Il fratel Antonio Presutti e i suoi Ricordi sopra i festeggiamenti nelle chiese e case della Compagnia di Gesù per la canonizzazione d'Ignazio di Loiola e Francesco Saverio, en La canonizzazione dei santi, pp. 87-93.

TURCHINI, Angelo, La fabbrica di un Santo. Il processo di canonizzazione di Carlo Borromeo e la Controriforma, Marietti, Casale Monferrato, 1984.

VERAJA, Fabijan, La beatificazione. Storia, problemi, prospettive, Roma, 1983.

VINCENT-CASSY, Cécile, Luchar por su santo. Rivalidades entre las órdenes religiosas en torno a las canonizaciones en el siglo XVII, en José Luis BETRÁN MOYA; Bernat HERNÁNDEZ y Doris MORENO (eds.), Identidades y fronteras culturales en el mundo ibérico en la Edad Moderna, Universitat Autónoma de Barcelona, Bellaterra, 2016, pp. 179-192.

VisCeglia, Maria Antonietta, La città rituale. Roma e le sue cerimonie in età moderna, Viella, Roma, 2002.

- Roma papale e Spagna. Diplomatici, nobili e religiosi tra due corti, Bulzone Editore, Roma, 2010.

- Guerra, diplomacia y etiqueta en la corte de los Papas (siglos XVI y XVII), Polifemo, Madrid 2010.

VVAA., La canonizzazione dei santi Ignazio di Loiola, fondatore della Compagnia de Gesù, e Francesco Saverio, Apostolo dell'Oriente. Ricordo del terzo centenario. XII marzo MCMXXII, Roma, 1922.

WRIGHT, Anthony D., «La sua santità non inclina niente»: The Papacy and the Canonization of Ignatius Loyola, en Thomas M. McCoog (ed.), Ite inflammate omnia. Selected bistorical papers from conferences beld at Loyola and Rome in 2006, Institutum historicum Societatis Iesu, Roma, 2010, pp. 441-455.

ZAZZERA, Francesco, Diario delle onoranze a San Filippo dalla morte alla canonizzazione (ed. a cura di Incisa della Rocchetta), en Quaderni dell'Oratorio, vI (1962), pp. 1-28. 